\title{
BIOMASSA E ASPECTOS NUTRICIONAIS DE CINCO ESPÉCIES DO GEENERO Eucalyptus, PLANTADAS EM SOLO DE BAIXA FERTILIDADE
}

\author{
HELTON DAMIN DA SILVA \\ Eng을 Florestal
}

Orientador: Prof. Dr. FÁBIO POGGIANI

Dissertação apresentada à Escola Superior de Agricultura "Luiz de Queiroz", da Universidade de São Paulo, para obtenção do título de Mestre em Engenharia Florestal.

\author{
PIRACICABA \\ Estado de São Paulo - Brasil \\ Novembro, 1983
}


.$e l$.

Aos meus pais

Aos meus irmãos 
. iii.

A minha esposa Regina

e a minha filha Fernanda

Dedico 
.iv.

AGRADEC IMENTOS

A todos aqueles que tiveram participação direta ou indireta, na realização deste trabalho, expresso meus sinceros agradecimentos, em especial:

- Ao Professor Dr. Fäbio Poggiani pela orientação e amizade;

- A Empresa Brasileira de Pesquisa Agropecuária pela oportunidade proporcionada;

- A Chefia do Centro de Pesquisa Agropecuária do Trópico Semi -Arido (CPATSA) pelo apoio e suporte financeiro;

- Ao Instituto Florestal de São Paulo na pessoa do Dr. Luiz Carlos Coelho que gentilmente cedeu a área experimental para coleta de dados;

- Aos docentes do Departamento de Silvicultura da ESALQ-USP pelos ensinamentos e pela orientação;

- Aos amigos e pesquisadores florestais do CPATSA pelo apoio e incentivo;

- Aos colegas do Curso de Pós-Graduação em Engenharia Floresta1 da ESALQ-USP, e em especia1, aos Engenheiros F1orestais Ricardo da Silva Pereira, pelo auxilio na coleta de dados e Ismae 1 Eleotério Pires, pela colaboração na revisão do texto; 
- Aos acadēmicos do Curso de Engenharia F1orestal da ESALQ- USP Vanderlei Benedetti, Silas Zen, Ivone S. Namikwa e Ro berto Chiaranda pelo auxílio na realização das anālises de laboratório;

- As funcionárias do Laboratório de Sementes do Departamento de Silvicultura, notadamente, a Srta. Rosana Maria Beltrame ;

- As funcionärias da biblioteca do IPEF;

- Aos funcionários do Departamento de Silvicultura pela atenção dispensada. 
1. INTRODUÇAO $\ldots \ldots \ldots \ldots \ldots \ldots \ldots \ldots \ldots \ldots \ldots \ldots \ldots \ldots \ldots \ldots$

2. REvisá de literatura $\ldots \ldots \ldots \ldots \ldots \ldots \ldots \ldots \ldots$

2.1. Amostragem de folhas, ramos, casca e lenho...4 4

2.2. Influência da espécie, procedèncias e clones na concentração e no conteúdo de nutrientes

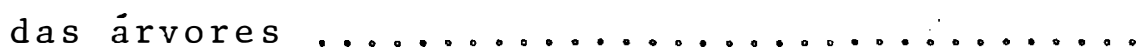

2.3. Concentração e conteúdo de nutrientes nas fo1has, ramos, casca e 1 enho $\ldots \ldots \ldots \ldots \ldots$

2.4. Influência da idade fisiológica na concentração e conteúdo de nutrientes nas folhas, ramos, casca e 1 enho $\ldots \ldots \ldots \ldots \ldots \ldots \ldots$

2.5. Influência do sitio na concentração e conteúdo de nutrientes das plantas $\ldots \ldots \ldots \ldots \ldots$

2.6. Variações nas concentrações de nutrientes em função do tamanho das: ärvores $\ldots \ldots \ldots \ldots \ldots$

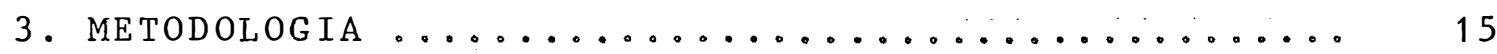

3.1. Descrição dos talhões experimentais $\ldots \ldots \ldots .15$

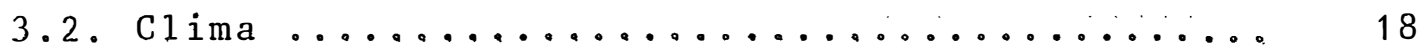

3.3. Caracteristicas do solo ................. 20

3.4 . Coleta de materiais vegetais $\ldots \ldots \ldots \ldots \ldots 22$

3.5. Determinações da densidade da madeira e da casca $\ldots \ldots \ldots \ldots \ldots \ldots \ldots \ldots \ldots \ldots$

3.6. Determinação do volume e peso dos troncos das árvores $\ldots \ldots \ldots \ldots \ldots \ldots \ldots \ldots \ldots \ldots \ldots \ldots \ldots \ldots \ldots$ 
vii.

pāgina

$3: 6.1$. Volume real com casca ............ 24

3.6.2. Peso dos troncos das ärvores ....... 25

3.7. Anālise química das amostras ............ 25

3.8. Determinação do conteúdo de nutrientes do le-

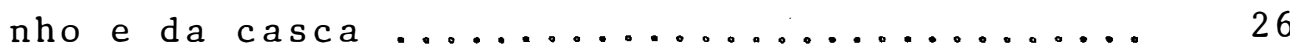

3.9. Indice de eficiência de utilização de nutrien tes das espécies estudadas ............... 26

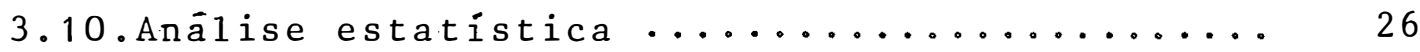

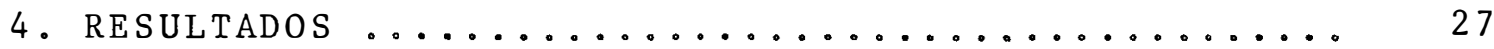

4.1. Caracteristicas dendrométricas ........... 27

4.2. Concentração mëdia de nutrientes nas folhas . 29

4.3. Concentração de nutrientes nos ramos ....... 32

4.4. Concentrações de nutrientes na casca ....... 32

4.5. Concentrações de nutrientes no 1 enho ....... 35

4.6. Conteüdo de nutrientes no 1 enho e na casca .. 35

4.7. Indice de eficiēncia de utilização dos nutri-

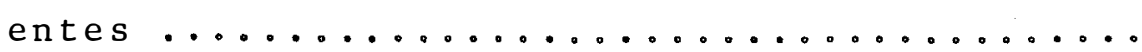

4.8. Variações das concentrações de nutrientes em função do tamanho das ärvores ............. 42

4.8 .1$. Nitrogēnio ................... 43

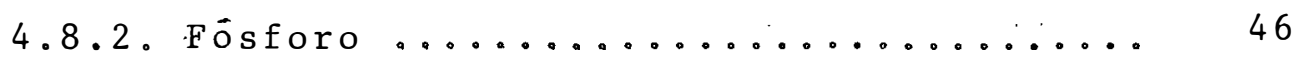

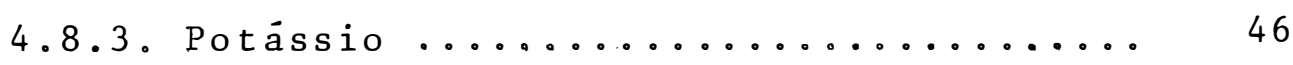

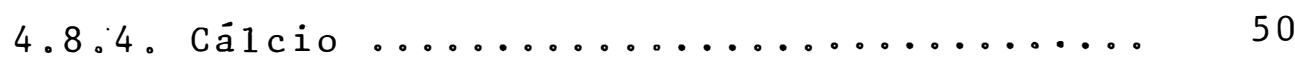

4.8 .5 . Magnèsio ..................... 50 
.viii.

pāgina

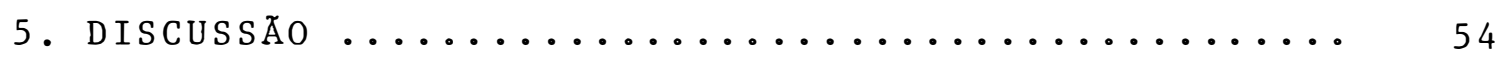

5.1 Caracteristicas dendrométricas ........... 54

5.2. Concentração e conteủdo de nutrientes nos diversos componentes das ärvores .......... 58

5.3. Indice de eficiēncia. de utilização dos nutri-

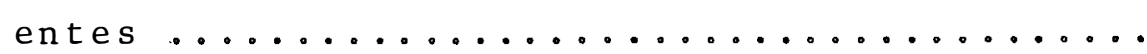

5.4. Variação das concentrações de nutrientes em função do tamanho das ärvores ............ 66

6. CONClusões E RECOMEndações .................. 74

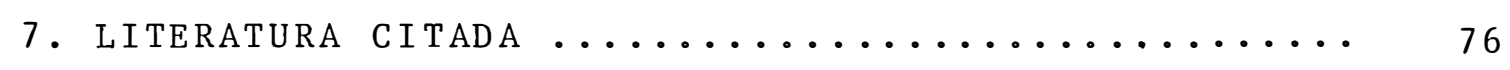

8. APENDICE $\ldots \ldots \ldots \ldots \ldots \ldots \ldots \ldots \ldots \ldots \ldots \ldots \ldots \ldots \ldots \ldots \ldots \ldots \ldots$ 


\title{
BIOMASSA E ASPECTOS NUTRICIONAIS DE CINCO ESPECIES DO GẼNERO Eucalyptus, PLANTADAS \\ EM SOLO DE BAIXA FERTILIDADE
}

\author{
Autor: HELTON DAMIN DA SILVA \\ Orientador: Prof. Dr. FÁBIO POGGIANI
}

RESUMO

A alta produtividade do gênero Eucalyptus. no Brasil, tem grande importancia do ponto de vista silvicultural e económico. O potencial de crescimento entre espécies implica também numa maior exportação de nutrientes por ocasião da exploração florestal.

Como a expansão da atividade reflorestadora vem sendo direcionada para solos de baixa fertilidade, a exploração florestal contínua pode provocar o empobrecimento ex cessivo desses solos. O conhecimento mais profundo do balanço de nutrientes e das implicações ecológicas de uma exploração florestal, são parâmetros essenciais para quantificar os problemas da exportação de nutrientes das áreas utilizadas pa ra o manejo intensivo de florestas plantadas.

Com o objetivo de se estimar o acúmulo de nutrientes por parte de cinco espécies de eucaliptos em função da biomassa produzida, foi utilizado um ensaio de competição 
. $x$.

com 10 anos de idade, envolvendo: E. grandis, $E$. saligna, $E$. propinqua, E. dunnii e E. robusta, todos de origem e procedēn cias australianas, plantados em solos arenosos e de baixa fer tilidade, em Itirapina - SP.

Foram avaliadas as caracteristicas dendrométri cas e coletadas amostras de folhas, ramos, casca e lenho de 12 árvore por espécie, para se estimar a produção de biomassa do tronco (lenho + casca), concentração de nutrientes, indices de eficiēncia de utilização de nutrientes para produção de biomassa no lenho e na casca e estimar a exportação de nutrientes por espécie.

Os elementos potássio, cälcio, magnésio, ferro, zinco e manganês foram determinados com espectrofotômetro de absorção atómica, o fósforo pelo método vanado-molibidato de amônio e o nitrogēnio pelo método microkjeldahl.

os resultados demonstraram que as espécies que produziram maior quantidade de biomassa no tronco foram E. sa ligna e E. grandis. Os nutrientes concntraram-se de forma de crescente nas folhas do ápice da copa, folhas da parte intermediária da copa, ramos, casca e lenho. Nas folhas, de um mo do geral, o E. dunnie apresentou as maiores concentrações de nitrogēnio e fósforo. os E. dunnie e E. robusta destacaram- se pelas altas concentrações de manganès nas folhas. Nos ramos, o E. dunnil apresentou a maior concentraça de nitrogẹ 
nio e o E. propinqua as mais altas concentrações de fósforo, potássio, cālcio e magnésio. Na casca, o E. saligna apresentou a maior concentração de cálcio e no lenho o $E$. grandis mostrou as menores concentrações de fósforo e potássio.

Do ponto de vista de "economia de nutrientes", seria recomendável a utilização de espécies com maior indice de utilização. Individualmente, por elemento, o E. dunnii é o mais eficiente para a utilização de nitrogēnio, o E.grandis é o mais eficiente para a utilização de fósforo e potássio e - E. propinqua para a utilização de cálcio e magnésio. De ma neira geral, para todos os nutrientes em ordem decrescente, os indices de eficiēncia apresentados em kg de biomassa produ zida por kg de cada nutriente utilizado (N, P, K, Ca e Mg) foram: E. grandis (54831); E. saligna (36389); E. dunnii (33900); E. propinqua (23444) e E. robusta (22639).

As correlações entre as concentrações dos dife rentes elementos e o tamanho das ärvores acusaram várias tendências de acordo com as espécies. Contudo, pode-se dizer que, de maneira geral, ocorreu um efeito de diluição dos elementos nitrogênio, magnésio e potássio em função do aumento do tamanho das ärvores. O E. grandis evidenciou uma capacida de maior de translocação do fósforo do lenho para as folhas. o E. saligna mostrou-se como uma espécie acumuladora de cálcio na casca. 


\title{
BIOMASS AND NUTRITIONAL ASPECTS OF FIVE ESPECIES OF
}

Eucalyptus PLANTED ON SOIL WITH LOW FERTILITY

\author{
Author: HELTON DAMIN DA SILVA \\ Adviser: Prof.Dr. FĀBIO POGGIANI
}

SUMMAR Y

The high productivity of species belonging to the genus Eucalyptus in Brazil has a great silvicultural and economic importance. The potential growth of these species also implies a more intensive nutrient exportation by logging.

Due to the fact that the reforestation activities have been directed to the utilization of soil with very low fertility, the continuos forest exploitation tends to cause excessive impoverishment of these soils. A more profound knowledge of nutrient balance and the ecological implications of man-made forests exploitation are essential for an appropriate management.

A competition trial was undertaken to estimate tree growth and nutrient accumulation of the following species: Eucalyptus grandis, E. saligna, E. propinqua, $E$. dunnii and $E$. robusta, established on a poor and sandy soil near by Itirapi na (State of São Paulo, Brazil). 
The dendrometric caracteristics of the stands 10 years old were evaluated, and samples were taken from leaves, twigs, bark and wood of twelve trees of each species, to estimate trunk phytomass (woody, and bark), nutrient concentration in the tissues and utilization efficiency of nutrients.

The results showed that the species with the highest trunk phytomass were $E$. saligna and $E$. grandis. Nutrient concentration in the tree tissues were observed decreasing in the following order: crown apex leaves, middle crown leaves, twigs, bark and wood. E. dunnie generally showed the highest nitrogen and phosphorus concentration in the leaves and the highest nitrogen level in the twigs. This species and $E$. robusta exhibited the highest levels of manganese in the leaves. E. propinqua showed the highest concentration of phosphorus, potassium, calcium and magnesium in the twigs, while E. saligna presented the highest calcium concentration in the bark and $E$. grandis the lowest of phosphorus and potasium in the wood.

In terms of "nutrient conservation in the site", the utilization of species with the highest efficiency index would be recomendable. Individually, for each nutrient treated separatelly, E. dunnie is the more efficient for nitrogen utilization, E. grandis for phosphorus and potassium 
. xiv.

and E. propinqua for calcium and magnesium. In general, the 'efficiency indexes" presented as phytomass produced (in kg) in relation to each $\mathrm{kg}$ used $(\mathrm{N}, \mathrm{P}, \mathrm{K}, \mathrm{Ca}$ and $\mathrm{Mg})$ were in decreasing order: E. grandis (54831); E. saligna (36389); $E$. dunnii (33900); E. propinqua (23444) and E. robusta (22639).

The correlation coeficients between the concentrations of the various nutrients and the size of the trees showed different trends according to the species. However, in general it was noted a dilution effect of nitrogen, magnesium and potassium according, to the increases in the size of the trees. E. grandis exhibited an higher capacity of translocating the phosphorus from the wood to the leaves in the bigger trees. E. saligna appears as a species accumulator of calcium in the bark. 
1. INTRODUÇAOO

As espécies do Gēnero Eucalyptus introduzidas no Brasil, para fins de florestamento e reflorestamento, permitem um ciclo de corte relativamente curto e uma alta produtividade quando comparadas com espécies florestais nativas. Apresentam portanto, uma grande importancia do ponto de vista econômico e silvicultural, uma vez que são utilizadas para produção em larga escala de papel, celulose e para fins energéticos, além de contribuir como matéria prima para confecção de chapas de fibras e aglomerados.

0 aumento do consumo de produtos florestais te ve como consequência a necessidade de elevação da produtivida de das florestas, com a adoção de técnicas alternativas tais como a redução do ciclo de corte e o aumento da densidade das ärvores, plantadas por unidade de ärea. Nas florestas utilizadas para fins energéticos, além da madeira, em muitos casos 
passou-se a explorar também os "resíduos" de exploração consti tuídos pelas folhas, ramos e casca das árvores.

O emprego destas técnicas causa preocupação, no que tange à exportação de nutrientes, uma vez que a maior concentração de nutrientes minerais está contida nos resíduos florestais. Isto pode implicar num acréscimo de quase $80 \%$ na exportação de nutrientes do sitio, considerando também que as árvores jovens apresentam uma concentração mais elevada de nu trientes do que as plantas adultas.

Portanto, o problema relacionado com a exporta ção de nutrientes pode ser melhor equacionado se houver um có nhecimento mais profundo das implicações da exploração flores tal sobre o balanço de nutrientes e de suas consequências eco 1 ógicas.

Este trabalho foi realizado com os seguintes objetivos:

a. Estimar a produção de madeira por diferentes espécies de Eucalyptys plantadas em solos arenosos e de baixa fertilidade;

b. Detectar as diferenças nas concentrações de nutrientes nas folhas, ramos, casca e lenho das espécies de Eucalyptus estudadas;

c. Comparar o acúmulo de nutrientes nas dife- 
rentes espēcies;

d. Estimar os indices de eficiēncia de utiliza ção de nutrientes para produção de biomassa no lenho e na casca e;

e. Observar se existe uma variação na concentração de nutrientes em função do tamanho das ärvores de cada espécie. 


\section{REVISÃO DE LITERATURA}

2.1. Amostragem de folhas, ramos, casca e lenho

o uso de amostras vegetais para avaliar o conteúdo de nutrientes, aparece como uma forma valiosa para se estudar as relações entre o crescimento e o nivel nutricional das plantas. A coleta de amostras para anālise de teor de nu trientes tem sido efetuada diferentemente por diversos pesqui sadores, visto não existir uma metodologia padronizada para diferentes espēcies arböreas.

Diversos fatores podem interferir nos resultados das análises sobre o conteūdo de nutrientes tais como: o procedimento da amostragem (LAVENDER e CARMICHAEL, 1966 e BOWERSOX e WARD, 1977b); a ṕoca do ano (WRITE, 1954 e HOYLE e MADER, 1964); a posição do material vegetal na copa (BOWERSox e WARD, 1977b; BOWERSOX e WARD, 1977a; ISIK, 1978 e EVANS, 
1979), e idade do material amostrado (LAVEndER e CARMICHAEL, 1966 e BOWERSOX e WARD。1977a).

Analisando värios critérios de amostragem de lenho e casca, Lubrano (1972) concluiu ser possivel, com pequena margem de erro, coletar amostras a 1,30 m do solo (DAP) e utilizar o resultado como média representativa do conteúdo mineral do tronco. No entanto, ZEN et alii (1981) demonstraram que em $E$. saligna a distribuição de $\mathrm{N}, \mathrm{P}, \mathrm{K}$ e $\mathrm{Mg}$ nem sempre é uniforme ao longo do caule, existindo um teor crescente de elementos minerais da base para o topo.

Todavia, young e CARPEnTER (1976) preconizam que a amostragem em uma posição central dos galhos, caule e raizes pode ser suficiente para estimar a concentração média dos nutrientes em cada um dos componentes das ärvores.

2.2. Influēncia da espécie, procedéncia e clones na concen tração e no conteúdo de nutrientes das árvores

Nutrientes, segundo JACOB e WEXKULL (1961) , são todos os materiais necessärios ao crescimento e produção de substāncias orgānicas; num sentido bem restrito, são consi derados os elementos inorgânicos essenciais ao desenvolvimento das plantas. 
As variações no conteúdo de nutrientes entre espécies, procedências, grupos de progênies, lotes de sementes e clones, deve-se a diferenças na capacidade do sistema radicular em absorver nutrientes do solo e ao grau de eficiên cia na translocação e na metabolização desses nutrientes (ME GEM e WORRAL, 1964 e WALKER e HATCHER, 1965).

Diversos estudos já foram desenvolvidos objeti vando detectar diferenças no conteúdo de elementos minerais em espécies florestais. De acordo com um artigo da revista SILVICULTURE (1964/65) foram detectadas diferenças entre mudas de E. rostrata, E. saligna, E. delegatensis e E. pilulalis. HAAG et alii (1976) e HAAG et alii (1977) apresentam resultados que evidenciam diferenças entre as espécies de $E$. grandis e E. citriodora para os teores de $\mathrm{N}, \mathrm{P}, \mathrm{K}, \mathrm{Ca}, \mathrm{Mg}, \mathrm{S}$, Cu, Fe, Mn e Zn. Hage, citado por BELlote (1979) detectou di 1. ferenças entre as folhas da parte superior e inferior da copa de E. grandis. FORREST e OVINGTON (1971) detectaram diferença significativa na concentração de nutrientes entre clones de Pinus radiata e BARTOS e JOHNSTON (1978) entre clones de Populus tremuloides.

2.3. Concentração e conteūdo de nutrientes nas

Os nutrientes, de acordo com sua função bioquí 
mica, acumulam-se diferentemente nos diversos componentes das plantas .

O montante de nutrientes contidos na biomassa florestal tem sido estudado por alguns pesquisadores. POGGIA NI et alii (1979) estudando um povoamento de E. grandis de 4 anos de idade observaram que a maior quantidade de biomas sa é representada pelo fuste (61\%), enquanto que a maior concentração de nutrientes ocorre nas folhas e, em seguida nos componentes: casca, galhos e lenho. POGGIANI et alii (1983) observaram que a biomassa de uma plantação para fins energét cos de E. grandis, aos 2,5 anos de idade, contém $9 \%$ de folhas, 7\% de galhos e $83 \%$ do material de tronco (lenho + casca), porém, a concentração de nutrientes ficou assim distribuida: $37 \%$ nas folhas, $10 \%$ nos galhos e $53 \%$ no tronco.

Segundo BELLOTE (1979), nas folhas, são observadas as maiores concentrações de nutrientes, com exceção do càlcio, cobre e manganès.

HAAG et alii (1976), estudando folhas de cinco espécies de Eucalyptus, concluiram que, entre espécies, houve diferenças nas concentrações de nutrientes e que o E. grandis apresentou concentraçóes mais elevadas para os macronutrientes $N, P, K$ e $S$.

RENNIE (1955) assinalou que a casca detém hif maior quantidade de cálcio, enquanto young e CARPENTER (1976) 
detectaram pouca diferença na composição mineral dos tecidos de ärvores maduras da mesma espécie. ZEN et alii (1981), estú dando variações de nutrientes ao longo do tronco de E. saligna, encontraram que a concentração de nutrientes tende a ser mais elevada na parte superior do tronco, sendo este fato mais evidente no lenho do que na casca.

2.4. Influēncia da idade fisiológica na concentração e con teūdo de nutrientes nas folhas, ramos, casca e lenho

A idade fisiológica do tecido é um fator impor tante, que afeta o seu nível nutricional (EVANS, 1979). Por isto, segundo LUBRANo (1972) e SWITZER e NELSON (1972) as plantas jovens normalmente acumulam maiores quantidades de nu trientes.

Em estudos comparativos de tecidos jovens e adultos em plantas, EVANS (1979) verificou que nas folhas mais velhas houve um decréscimo nas concentrações de $N$ e $K$ e um aumento de Fe, B, Mn e Ca. TEMES (1970). encontrou nas folhas dos ramos superiores de E. globulus uma tendencia para o acúmulo de $\mathrm{N}, \mathrm{P}, \mathrm{Mg}, \mathrm{Cu}$ e $\mathrm{Zn}$.

As concentrações de nutrientes podem variar de acordo com a idade das ärvores, época de coleta e local da amostragem (LAVENDER e CARMICHAEL, 1966). Isto foi comprova- 
do por Forrest, citado por ForRest e OVINGTON (1971), o qual afirma que antes do povoamento florestal entrar em competição, a copa contêm de 70 a $80 \%$ do total de nutrientes. Young e CARPENTER (1976), estudando coníferas de diferentes idades, encontraram diferenças no conteūdo mineral das plantas mais jovens em relação as plantas adultas. BELLOTE (1979) comparou o conteúdo de nutrientes nas plantas de $E$. grandis de 1 a 7 anos de idade e verificou que as concentraçóes de $N$, P e K eram menores nas plantas mais velhas, com exceção do Ca. Observou também que, $98 \%$ do $\mathrm{P}$ e Mg são acumulados atē o $6 \%$ ano e $99,4 \%$ do Zn até o 5 \% ano.

2.5. Influencia do sîtio na concentração e conteūdo de nutrientes das plantas

0 conteúdo de nutrientes nas plantas pode ser influenciado pela capacidade de absorção de cada espécie e pe la natureza e propriedades químicas do solo. Em regiões temperadas, onde o ciclo da cultura florestal é normalmente longo, e exploração dos resíduos florestais não representaria uma perda acentuada no bal anço geral do ecossitema florestal. Porēm, quando se trata de solos pobres e arenosos, commuitos que ocorrem em regiões tropicais e sub-tropicais, essa exploração pode causar sérios prejuízos à rotação seguinte (WEETNAM e WEBBER, 1972)。 
Segundo POGGIANI et alii (1979), devido à fragilidade dos ecossistemas florestais no Brasil, as práticas de manejo e exploração como as "mini-rotações" podem ser pouco adequadas e merecem estudos mais detalhados antes de serem implementadas. Observaram também que,face ao custo dos fer tilizantes, a reposição adequada dos nutrientes retirados do sitio através da exploração exige um investimento elevado. Contudo, esta reposição torna-se obrigatória para garantir a produtividade da floresta na rotação seguinte.

Em climas tropicais e subtropicais, onde os solos utilizados para plantações florestais apresentam quase sempre condições de fertilidade extremamente baixas, a exploração dos residuos pode ser altamente prejudicial (HAGNER, 1971). Nestes solos hä necessidade de estudos mais detalhados sobre a exportação de nutrientes, para que haja um melhor entendimento dos efeitos do sitio e da produtividade das florestas.

No Brasil, a expansão da silvicultura tende a ocupar solos de baixa fertilidade e para que a produtividade seja garantida, as técnicas de plantio e a busca de espécies menos exigentes devem ser alvo de estudos (MEllo et ali $i$, $1971)$.

Existe estreita correlaçäo entre o conteüdo de nutrientes no solo e nas plantas. McColl (1967) observou, em 
Eucalyptus, correlações positivas entre o fósforo nas folhas e seu conteúdo no solo. Verificou também que, a presença de cálcio e magnésio no solo favorece a absorção de fósforo pelas plantas. TEMES (1970), trabalhando com árvores de E. glo bulus de diferentes idades plantadas em solos arenosos e pobres, observou correlações entre os teores de cálcio e manganès nas folhas e no solo.

As variações nos teores de nutrientes podem ocorrer por värios motivos. CZAPOWSKYJ (1979) observou que as condições de drenagem do solo e as práticas silviculturais po dem influenciar os niveis de nutrientes das árvores de Abies balsamea (L) Mill, pois em solos de pouca drenagem o N, P e Mn aparecem em baixas concentrações. Resultado semelhante foi obtido por HOYLE e MADER (1964) e por ISIK (1978) que constataram, em diferentes tipos de solos, variações altamente significativas no conteúdo de N, P, Ca, Mg e Mn em Abies concolor.

Diferenças de concentrações de nutrientes nas folhas podem ser observadas numa mesma espécie que apresente uma área de ocorrência muito ampla ou situada em locais com solos muito heterogēneos (FORREST e OVINGTON, 1971). 
2.6. Variações nas concentrações de nutrientes em função do tamanho das ārvores

As comparações entre as concentrações de nutrientes nas árvores de uma floresta plantada entre os indiví duos de diferentes tamanhos, não é um assunto amplamente estu dado. ivormalmente são estudadas plantas com idades diferentes.

A composição química de uma espécie é grandemente afetada pelo ambiente em que vive. Em condições naturais, as espécies têm diferentes adaptações que se refletem no vigor, ramificações, tamanho das folhas, necessidade de 1 uz e também diferenças na absorção dos constituintes qüimi$\cos ($ BATES, 1971).

A posição das folhas na copa propicia variações nutricionais de acordo com a exposição à luz solar. Segundo EVANS (1979), o aumento do sombreamento favorece um decréscimo nos níveis de $N, P, Z n$ e $B$ e provoca um acréscimo nos niveis de Ca e Fe em folhas de Gmelina arborea. BURR (1961) detectou grande interação entre a intensidade luminosa e a concentração de nitrogênio nas folhas e raizes de cana-de-açu car. Schimidt e Blaser, citados por BATES (1971), encontraram resultados semelhantes em Cynodon sp.

A umidade do solo também afeta as concentra- 
ções de nutrientes nos tecidos vegetais e segundo CANNEL et alii (1959), as concentrações de P, B e Mo decrescem com défi cit hídrico, porém, as concentrações de Ca e $\mathrm{Mg}$ aumenta. Se gundo BURR (1961), as temperaturas do solo e do ar afetam as concentrações de fósforo na cana-de-açúcar.

Além dos fatores água, nutrientes, luz e tempe ratura que afetam o crescimento e produção das culturas, os tecidos vegetais apresentam diferentes concentraçoes de nutrientes em função da idade (WHIte, 1960). Segundo Lonergam e Snowbal1, citados por BATES (1971), os nutrientes pouco móveis, notadamente o cálcio, não se deslocam facilmente para os tecidos mais jovens, mesmo quando estes apresentam sinais de deficiência. EVANS (1979) verificou que há uma alta concentração de fósforo e cálcio onde a atividade de crescimento dos tecidos é maior.

A maior ou menor taxa de crescimento pode provocar um acréscimo ou diminuição na concentração de nutrientes das árvores. Segundo RAIJ (1981), a diminuição nas concentrações de nutrientes deve-se a 'ım efeito de diluição proporcionado pela maior produção de matéria seca.

Diferenças nas concentrações de nutrientes em ärvores com menor ou maior taxa de crescimento foram observadas por POGgIANI (1983)*em urna população de E. saligna, de 8 
anos de idade, plantada em solo pobre, sem adubação, apresentando alta taxa de mortalidade e com domināncia nítida das ār vores remanescentes. Nessas, foi observada uma concentração mais elevada de nutrientes. Ao conträrio, num plantio energé tico cortado aos 2,5 anos de idade e fortemente adubado, hou ve uma maior concentração de nutrientes nas folhas das ärvores dominadas. 


\section{METODOLOGIA}

\subsection{Descrição dos talhões experimentais}

o experimento utilizado para avaliar a biomassa, a concentração e o conteúdo de nutrientes em diferentes espécies de Eucalyptus foi um ensaio de competição entre espê cies plantado em Itirapina (SP) e formado a partir de sementes introduzidas da Austrälia e cujos locais de origem são apresentados na Tabela 1 .

No ensaio, plantado em março de 1973, utilizou-se o delineamento estatístico de blocos ao acaso, com qua tro repetições e parcelas de 64 plantas no espaçamento de 3 x $3 \mathrm{~m}$. Não houve aplicação de adubo e nem calcáreo. 0 croqui de instalação do experimento no campo é apresentado na Fi gura 1 . 
.16 .

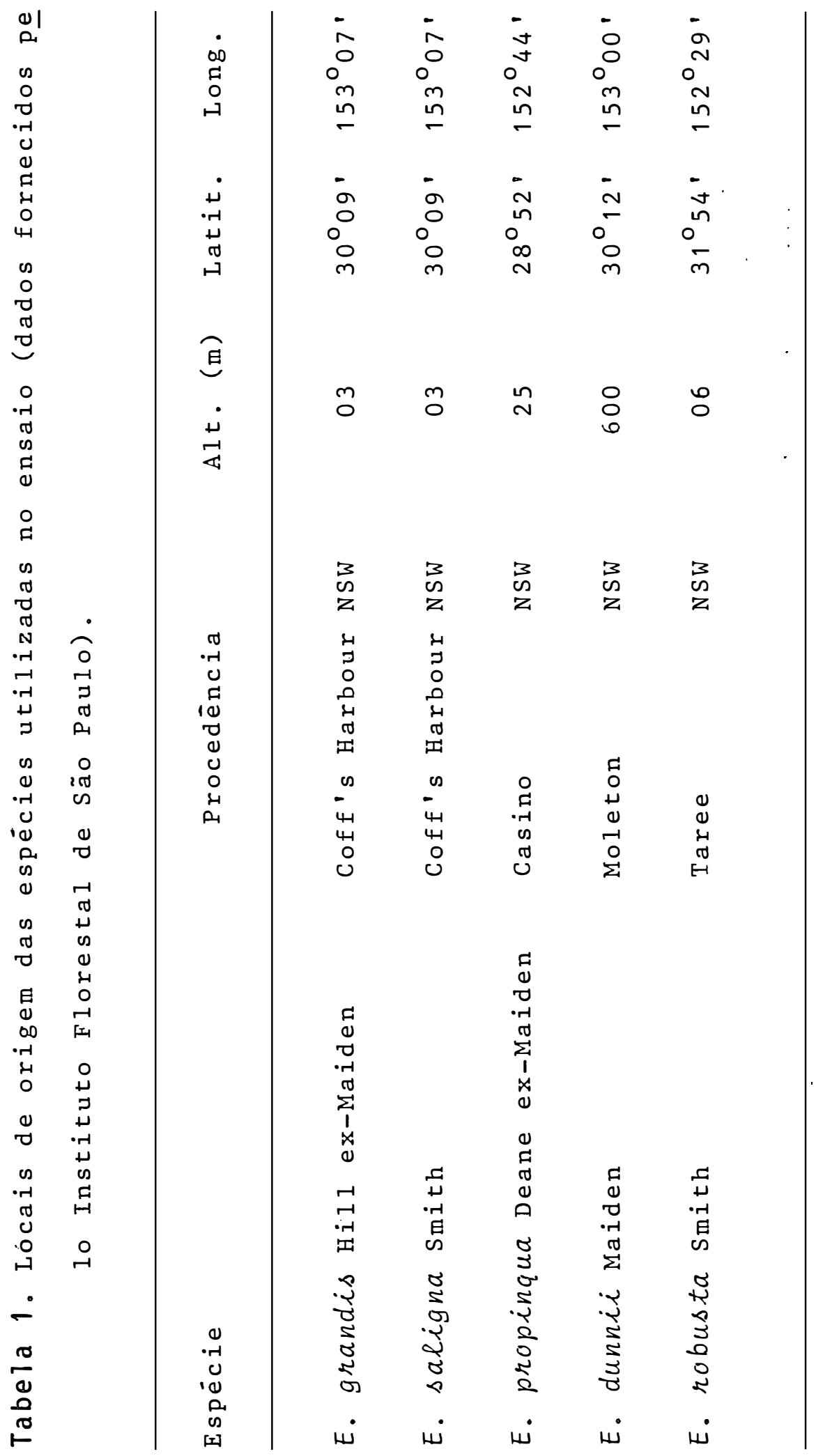




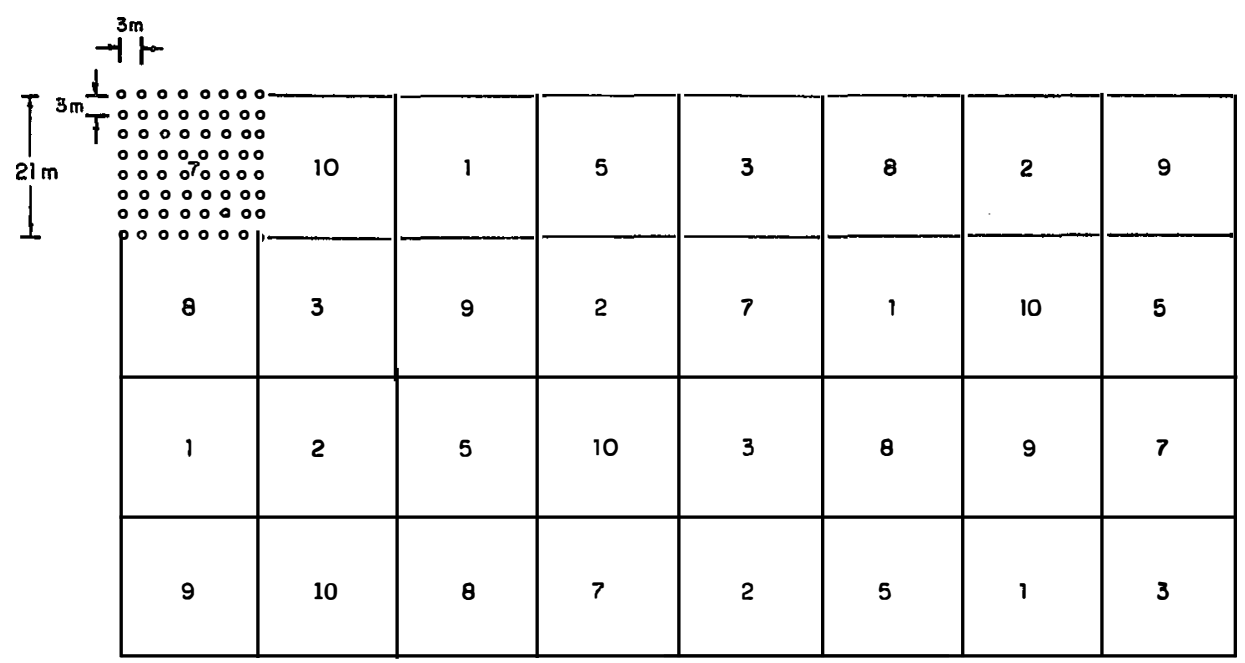

Figura 1. Croqui de campo para localização das parcelas de Eu calyptus plantadas em Itirapina (SP), pelo Instituto Florestal de São Paulo. Identificação: 1. E. grandis $(*) ; 2$. E. saligna (*); 3 . E.propinqua (*); 5. E. dunnii (*);7. E. microcorys; 8. E. robusta (*);9. E. acmenioides e 10. E. resinifera.

(*) Espécies utilizadas nesta pesquisa. 
3.2. Clima

Segundo VENTURA et alii (1965/66), e baseado na classificação do köppen, o clima da região de Itirapina (SP) é do tipo mesotérmico úmido, com inverno seco, temperatú ra do mês mais quente superior a $22^{\circ} \mathrm{C}$, e a do mès mais frio inferior a $17^{\circ} \mathrm{C}$. Há ocorrēncia de geadas esporádicas. A pre cipitação média anual está entre 1200 e $1400 \mathrm{~mm}$, sendo os meses mais chuvosos os de novembro a março.

O diagrama climático da região de Itirapina, construido segundo o método de WALTER (1977), foi preparado a partir dos dados compilados por VEIGA (1975) e está representado na Figura 2.

o experimento está situado na estação experimental de Itirapina, pertencente ao Instituto Florestal de São Paulo. Esta região localiza-se a $22^{\circ} 15^{\prime}$ de latitude Sul e $47^{\circ} 49^{\prime}$ de longitude a Oeste de Greenwhich e a uma altitude de $760 \mathrm{~m}$. 
ITIRAPINA:

LAT. $22^{\circ} 15^{\prime} \mathrm{S} \quad$ LONG. $47^{\circ} 49^{\prime} \mathrm{W} \quad$ ALT. $760 \mathrm{~m}$

.19 .

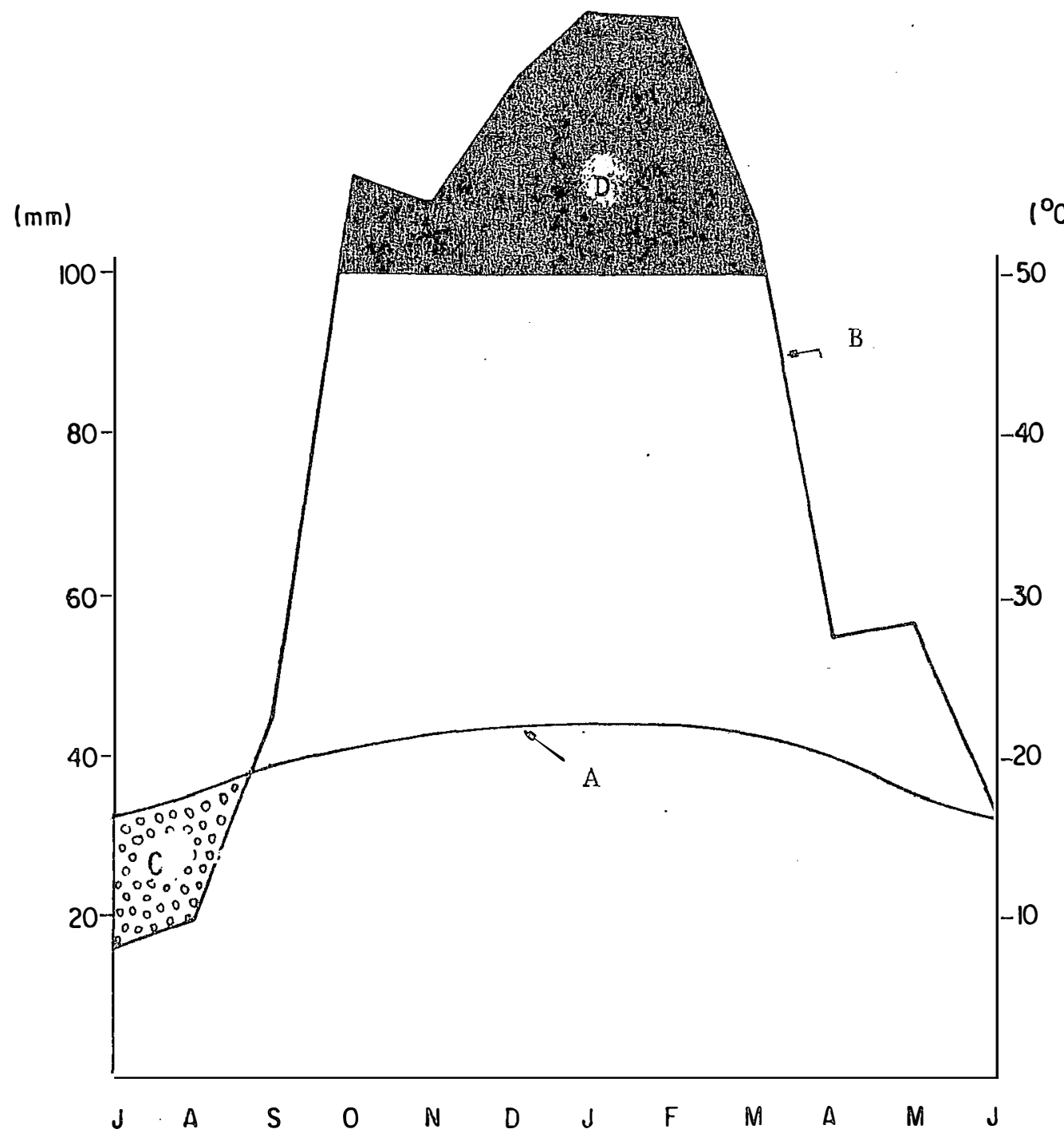

Figura 2. Diagrama climático representativo da região de Itirapina - SP.

Precipitação anual (média) = $1425 \mathrm{~mm}$

Temperatura média do mês mais frio $=16,2^{\circ} \mathrm{C}$

Temperatura média do mês mais quente $=22,3^{\circ} \mathrm{C}$

A - curva de temperatura

B - curva de pluviosidade

C - período seco

D - período com chuva acima de $100 \mathrm{~mm}$. 


\subsection{Caracteristicas do solo}

A amostragem do solo, para as anälises físicas e quimicas da ärea onde estão implantados os talhões, constou de amostras simples de cada bloco experimental coletadas a 0,$10 ; 0,50$ e $1,00 \mathrm{~m}$ de profundidade, transformadas posteriormente em uma amostra composta para cada profundidade, de acordo com RAIJ (1981). As amostras foram analisadas pelo De partamento de Solos, Geologia e Fertilizantes da ESALQ-USP em Piracicaba .

O experimento está instalado em um solo class ficado como areia quatzosa, cujas características físico-químicas apresentadas na Tabela 2 revelam, para as três profundidades analisadas, um solo pobre para todos os nutrientes, com alto teor de alumínio e $\mathrm{pH}$ ácido. 

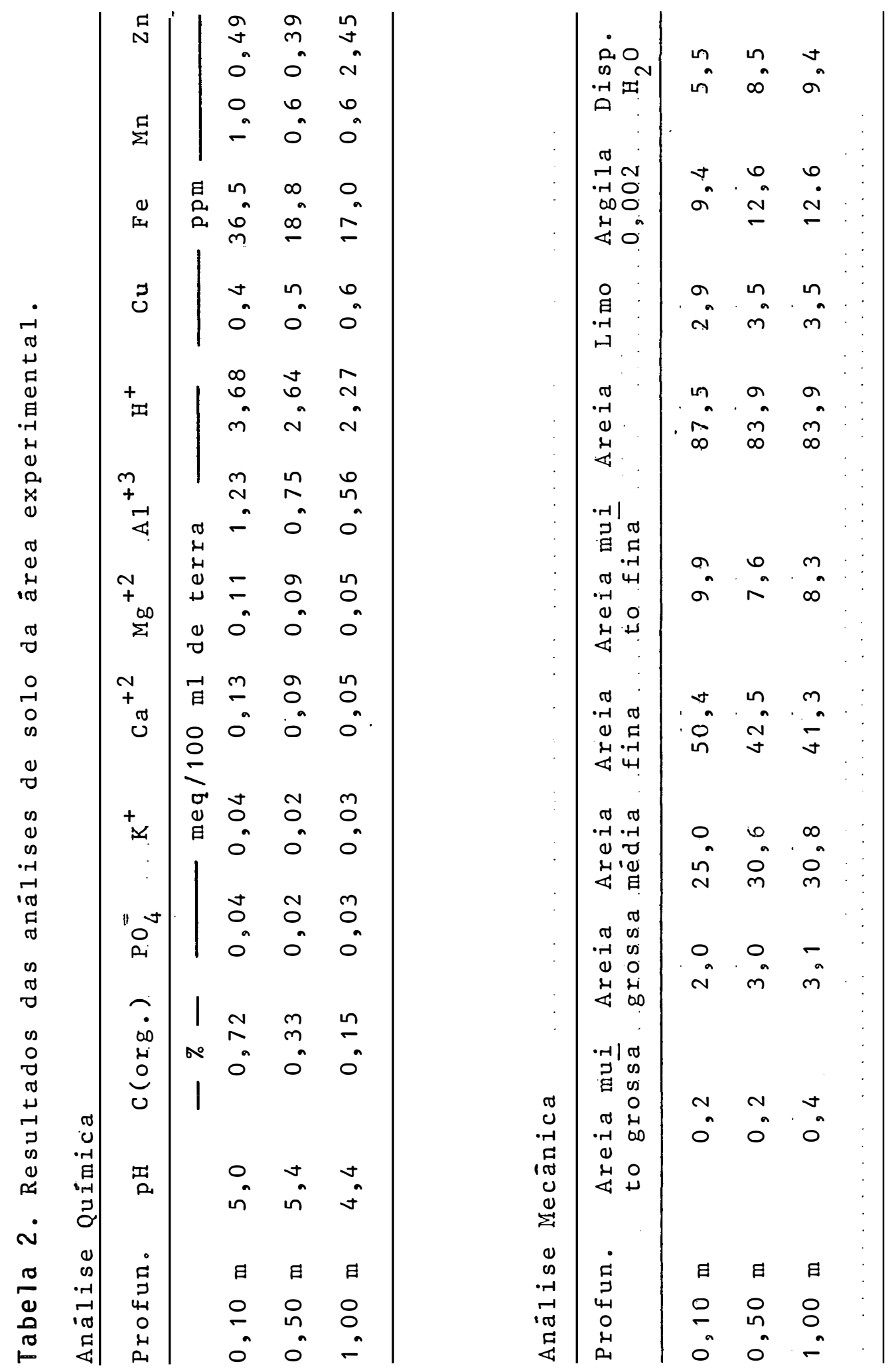
3.4. Coleta de materiais vegetais

Para as anālises químicas, as amostras dos diferentes componentes das plantas foram obtidas a partir de três árvores por parcela, totalizando doze árvores por espécie.

A escolha das árvores foi feita combase na me dição prévia de todas as ärvores das parcelas separadas em três classes de altura: dominantes, codominantes e dominadas. Para a coleta - das amostras, foram utilizadas ärvores representativas da média de cada classe de altura.

Das árvores abatidas, foram tomados dados de a 1 tura comercial do fuste (altura que vai da base até o diâmetro de $6 \mathrm{~cm}$ ) e a cada segmento de 3 metros foi anotado o diâmetro do tronco e a espessura da casca. A determinação do vo lume real do tronco com casca, sem casca e volume da casca, foi feita através da formula de Smalliam.

$$
V=\frac{1}{2}\left(\frac{\pi D^{2}}{4}+\frac{\pi d^{2}}{4}\right) h
$$

onde:

$$
\begin{aligned}
\mathrm{V}= & \text { volume do segmento (com casca e sem casca) } \\
\mathrm{D}= & \text { diâmetro maior do segmento (com casca e } \\
& \text { sem casca. } \\
\mathrm{d}= & \text { diâmetromenor do segmento (com casca e } \\
& \text { sem casca. }
\end{aligned}
$$


$h=$ comprimento do segmento.

o volume real do tronco è dado pelo somatório dos segmentos que compõem a árvores.

Para determinar a concentração média dos nutrientes na biomassa, foram retiradas amostras das folhas e ramos da parte intermediāria da copa, em cada um dos pontos cardeais, e também do lenho e da casca a partir de um disco localizado na parte intermediāria do fuste (YOUNG e CARPENTER, 1976). Foram ainda retiradas amostras das folhas do ano localizadas no äpice da copa para anālise nutricional.

3.5. Determinações da densidade básica da madeira e da cas ca do tronco das ārvores abatidas

A densidade básica média da madeira e da casca do tronco foi determinada pelo método da balança hidrostática, segundo as normas da ABCP M14/70*. Foi utilizado um disco retirado da parte intermediária do tronco de cada ärvore das doze amostradas por espécie. Os discos foram levados para o laboratório do Setor de Química, Celulose e Energia do Departamento de Silvicultura da ESALQ-USP, onde foi determinada a densidade bāsica média utilizando-se da seguinte fórmula:

* Normas de ensaio da Associação Técnica B̈rasileira de Celulo se e Pape 1 . 


$$
\mathrm{db}=\mathrm{PS} /(\mathrm{PU}-\mathrm{PI})
$$

Onde:

$$
\begin{aligned}
& \mathrm{db}=\text { densidade bäsica média do disco } \\
& \mathrm{PS}=\text { peso seco do disco em estufa a } 105 \pm 3^{\circ} \mathrm{C} . \\
& \mathrm{PU}=\text { peso ümido saturado do disco } \\
& \mathrm{PI}=\text { peso imerso }
\end{aligned}
$$

3.6. Determinação do volume com casca, sem casca e peso sê co do tronco da ārvore em pé

\subsubsection{Volume real com casca e sem casca}

Para determinação do volume real com casca e sem casca da ārvore em pé de cada espécie, empregou-se a equa ção de determinação de volume usualmente utilizada no Departa mento de Silvicultura da ESALQ/USP? para diferentes espécies de Eucalyptus plantadas na região do cerrado.

$$
V R=0,05 \times\left(D^{2} H\right) 0,9631
$$

onde:

$$
\begin{aligned}
& V R=\text { volume real com casca e sem casca } \\
& D \text { = diâmetro a altura do peito com casca e sent } \\
& \text { casca } \\
& \mathrm{H}=\text { altura total do tronco } \\
& 0.9631=\text { constante }
\end{aligned}
$$

* Dados fornecidos pelo Prof. Hilton Thadeu Zarate do Couto 
3.6.2. Peso seco dos troncos das ārvores

o peso dos troncos das ärvores foi estimado a partir do volume real, determinado em 3.6.1., utilizando-se a fórmula:

$$
P=V R \times d
$$

onde :

$$
\begin{aligned}
& P=\text { peso total do tronco da árvore } \\
& V R=\text { volume real total da parcela em pé } \\
& \mathrm{d}=\text { densidade básica média dos discos obtidos } \\
& \quad \text { nas doze árvores abatidas. }
\end{aligned}
$$

3.7. Anālise quīmica das amostras

As amostras de folhas, ramos, casca e lenho fo ram colocadas para secar em uma estufa de ventilação forçada, a $70-75^{\circ} \mathrm{C}$, até alcançar peso constante. Em seguida, para determinação das concentrações dos nutrientes, o material foi triturado em moinho tipo wiley e peneirado com malha 20.

As determinações de K, Ca, Miğ, Fe: Zn, Cu e Mn fo ram efetuadas com espectrofotōmetro de absorção atōmica, o fósforo pelo método Vanado-molibidato de amônio e o nitrogènio pelo método do Micro Kjeldahl, de acordo com SARRuge e HAAG (1974). 
3.8. Determinacão do conteūdo de nutrientes no lenho e na $\dot{\mathrm{c} a s c a}$

Cs conteúdos de nutrientes na biomassa do lenho e casca de cada espécie foram estimados multiplicando-se os valores dos teores de nutrientes encontrados no lenho e na casca pelos valores de biomassa de cada componente das árvores.

3.9. Indice de eficiēncia de utilização de nutrientes

0 indice de eficiência de utilização de nutrientes foi calculado em kg de matéria seca produzida por kg de nutriente utilizado, de acordo com os conceitos fundamenta dos nos trabalhos de HANSEN e BAKER (1979).

3.9. Indice de eficiência de utilização de nutrientes

Os valores foram analisados através do teste de Tukey e curvas de regressão, relacionando os parâmetros: altura (H), diâmetro à altura do peito (D) e diâmetro à altura do peito ao quadrado $x$ altura $\left(D^{2} H\right)$, com os teores de nutrientes nas folhas do äpice, parte intermediāria da copa, ra mos, lenho e casca. 
.27 .

\section{RESULTADOS}

4.1. Caracteristicas dendrométricas

As características de altura, diâmetro, volume, densidade, peso e sobrevivencia podem ser observadas na Tabela 3. O E. grandis teve um crescimento em altura mais acentuado. Em volume, as duas espécies que apresentaram performance melhor do que as demais foram E. grandis e E. salig na. As espécies que apresentaram menor crescimento em altura, diāmetro e volume, tiveram maiores valores para densidade, destacando-se o E. propinqua, com uma densidade no lenho de $0,634 \mathrm{~g} / \mathrm{cm}^{3}$. 


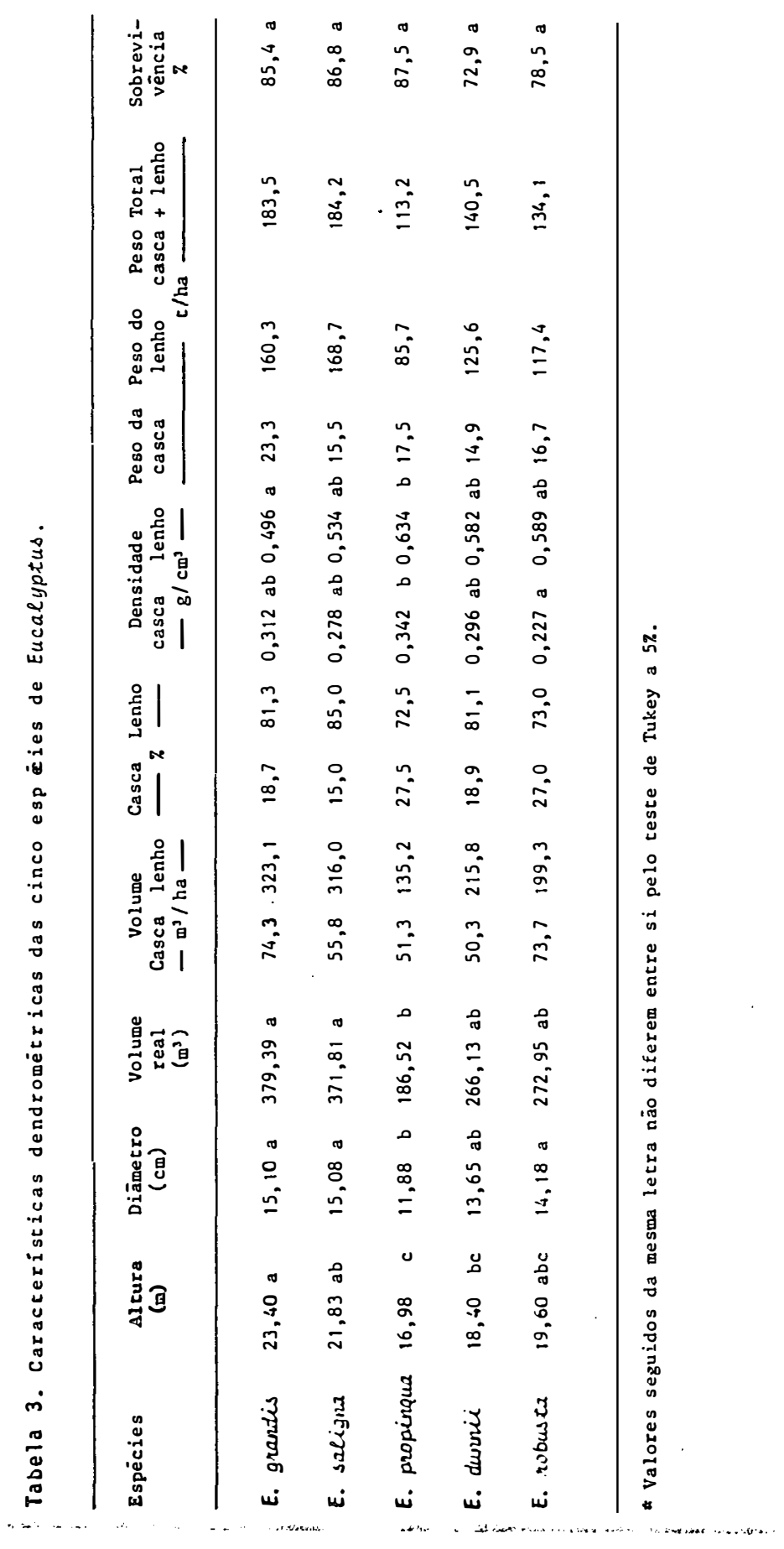


4.2. Concentrações médias de nutrientes nas folhas

As concentrações médias de nutrientes nas fo1has do ápice da copa de cada uma das espécies estudadas encontram-se na Tabela 4. A seguir, na Tabela 5 são apresentadas as concentrações médias de nutrientes nas folhas da parte intermediária da copa.

o E. grandis é a espécie que apresenta as meno res concentrações de $N$ e $P$ nas folhas do ápice dá copa, sendo que as concentrações de $K$ não apresentam diferenças significa tivas entre as espécies. Ainda na Tabela 4, observa-se que o E. dunnii tem maiores concentrações de $N$ e P. O E. dunnii e - E. robusta destacam-se pela alta concentração de Mn.

Em termos médios, os valores das concentrações de nutrientes encontrados nas folhas da parte intermediária da copa, são menores do que aqueles encontrados nas folhas do ápice. Sabe-se que o material oriundo do ápice da copa refle te me1hor as condições nutricionais das espécies. Como excegão deverse assinalar que, de maneira geral, a concentração de eáleio maior nas folhas da parte intermediária da copa do gue ne. 


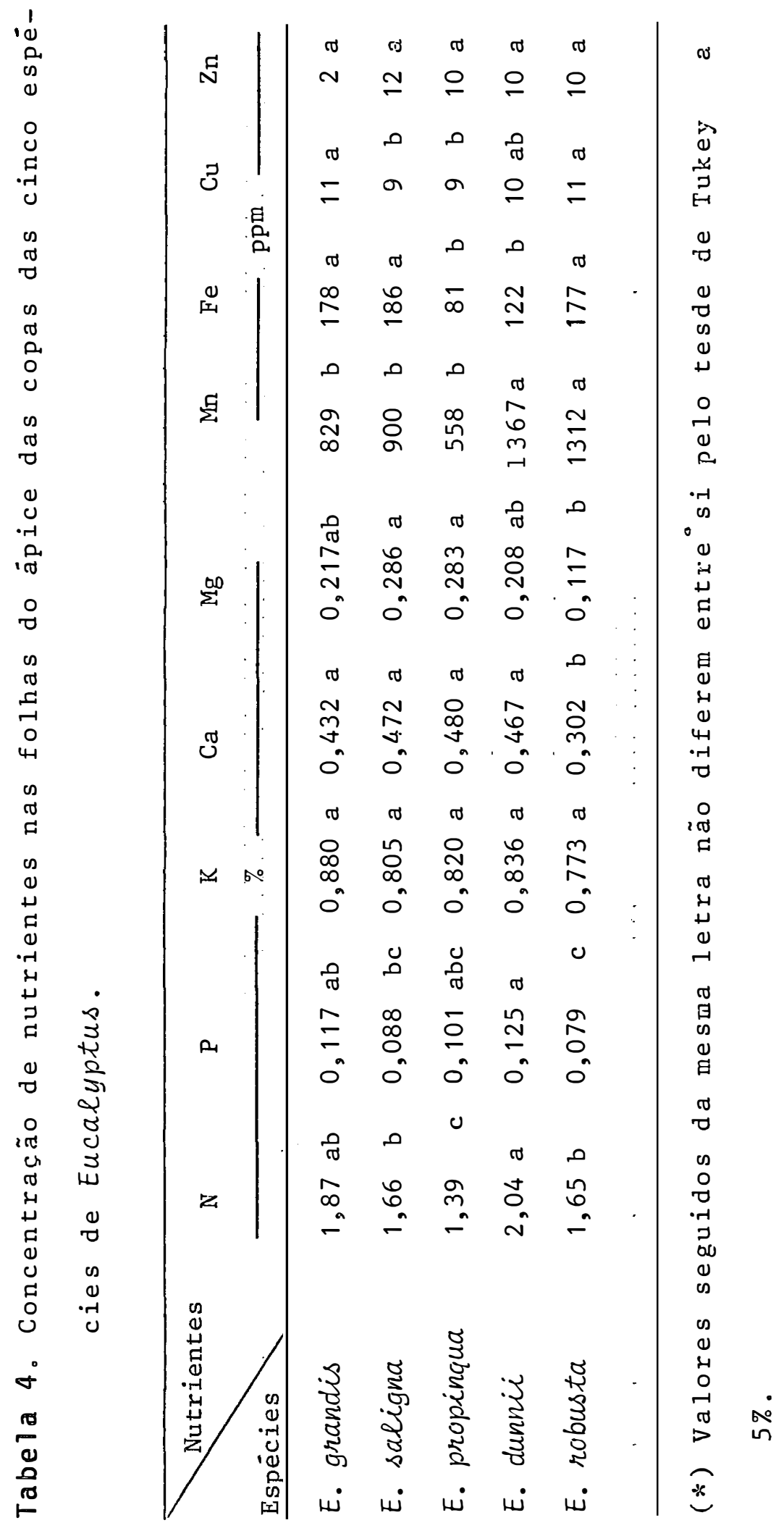




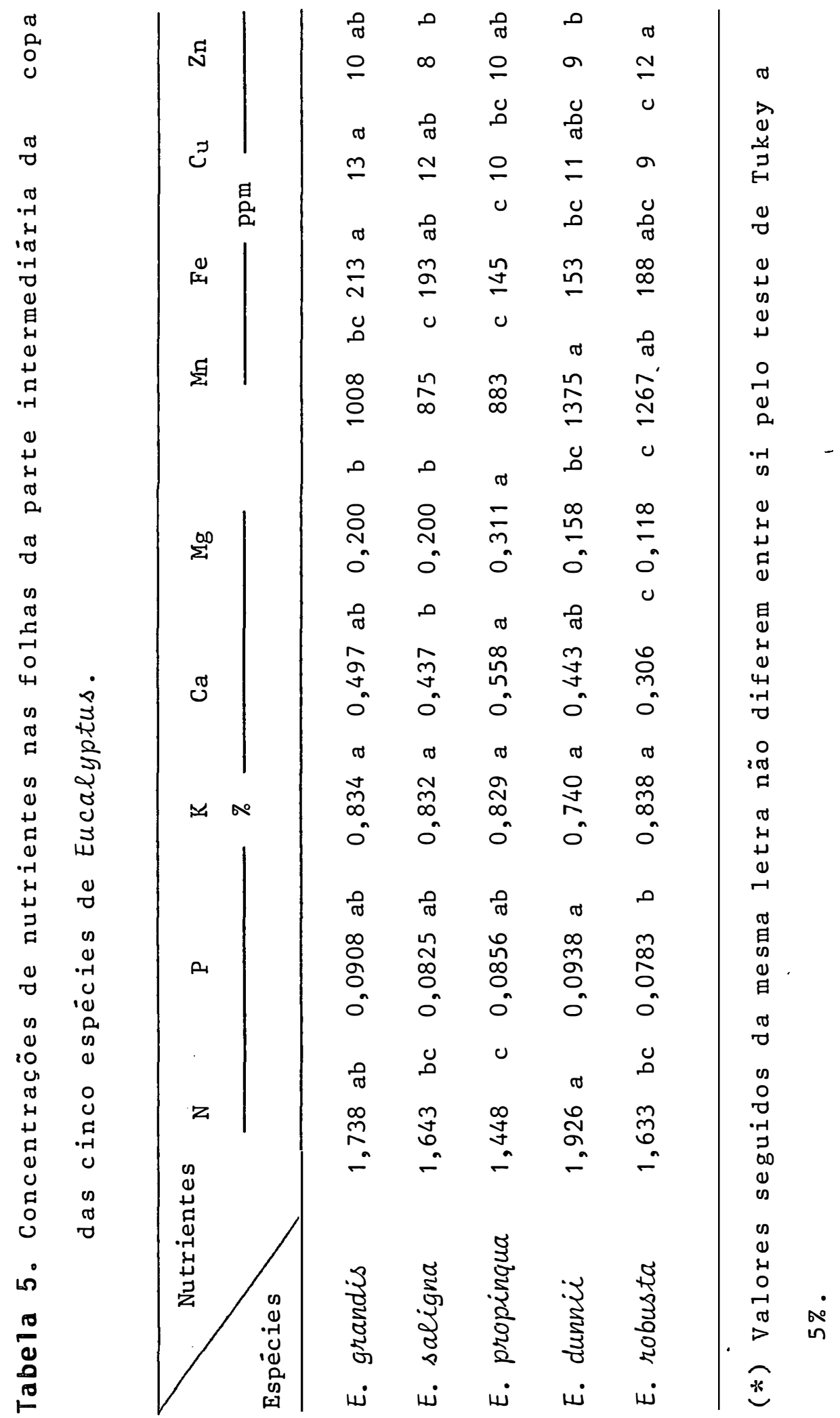


4.3. Concentração de nutrientes nos ramos

As concentrações de nutrientes nos ramos encon tram-se na Tabela 6 , onde se observa que de maneira geral, são mais baixas do que as concentrações observadas nas folhas. 0 E. dunnii possui a maior concentração de $N$ e $O E$. propinqua as maiores concentrações de $\mathrm{P}, \mathrm{K}, \mathrm{Ca}$ e $\mathrm{Mg}$. As elevadas concentrações de Mn observadas nas folhas das espécies de E. dun nii e E. robusta não são observadas nos ramos.

4.4. Concentração de nutrientes na casca

Na Tabela 7 são apresentadas as concentrações médias de nutrientes para as cinco espécies de Eucalyptus estudadas. De um modo geral, a casca apresenta: concentrações de nutrientes mais baixasdo que as folhas e os ramos. Todavia, deve ser salientado que o cálcio, de maneira geral, apresenta concentraçoes mais elevadas na casca do que nas folhas, destacadamente o E. saligna. O E. dunnii apresenta o teor mais elevado de potássio. Dentre os micronutrientes, de ve-se assinalar que a casca de $E$. propinqua apresenta uma con centraça de Fe cerca de dez vezes mais elevada do que nas fo 1has. 


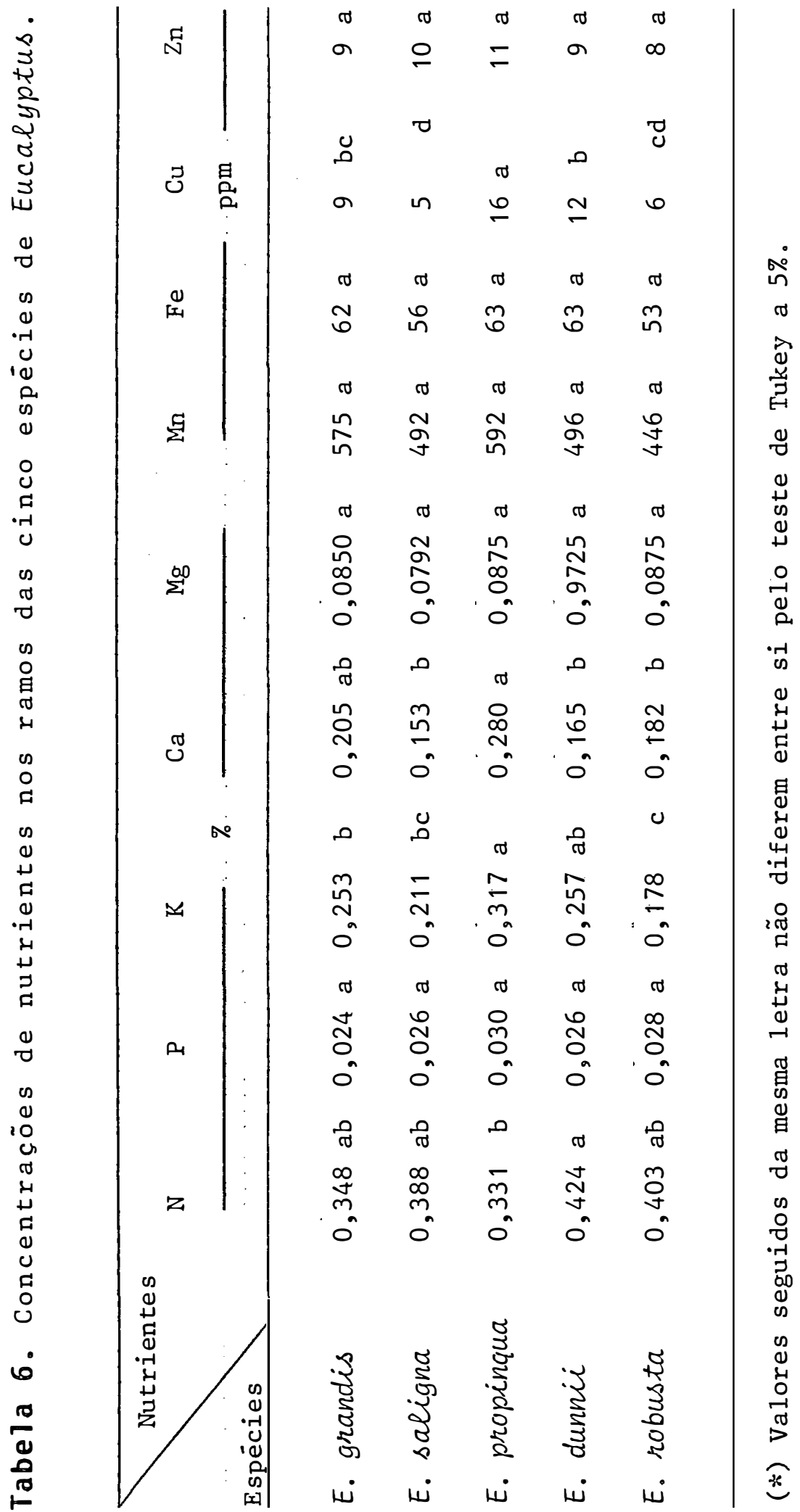




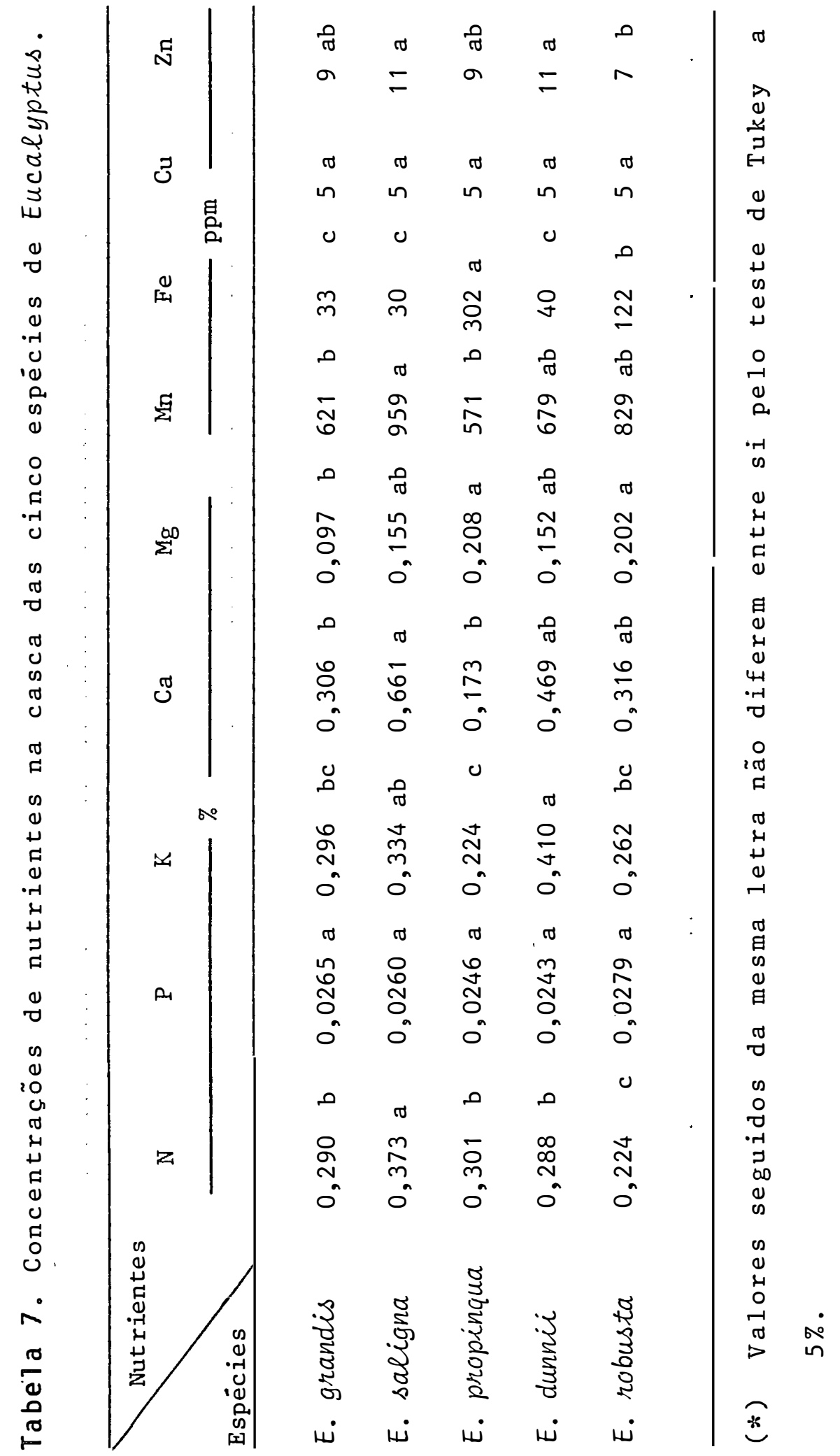


4.5. Concentrações de nutrientes no renho

As concentrações de nutrientes no lenho das cinco espécies em questão são apresentados na Tabela 8. Pode -se observar nesta tabela, que as concentrações dos elementos sao em geral menores do que aquelas encontradas nas folhas, ramos e casca das árvores. Para o fósforo e potássio, as con centrações no lenho são,em média, respectivamente $17 ; 14$ ee 8 vezes mais baixas do que nas folhas.

4.6. Conteúdo de nutrientes no lenho e na casca:

A distribuição dos nutrientes nos vários compo nentes das ärvores tem grande importāncia na nutrição de povoamentos florestais manejados em rotações sucessivas. O manejo intensivo das plantações pode aumentar significativamente a produção de biomassa, mas também, aumenta a remoção de nutrientes do sitio, a qual é influenciada basicamente por três fatores: o volume, a densidade e a concentração de nutri entes.

As maiores concentrações de nutrientes em ärvo res estão nös tecidos das copas. No entanto, a maior quantidade de biomassa encontra-se no tronco (POGGIANI et alii, 1979), que. é a parte normalmente mais explorada. o conteúdo de nutrientes ( $\mathrm{kg} / \mathrm{ha}$ ) de biomassa do lenho das cinco espécies 
.36.

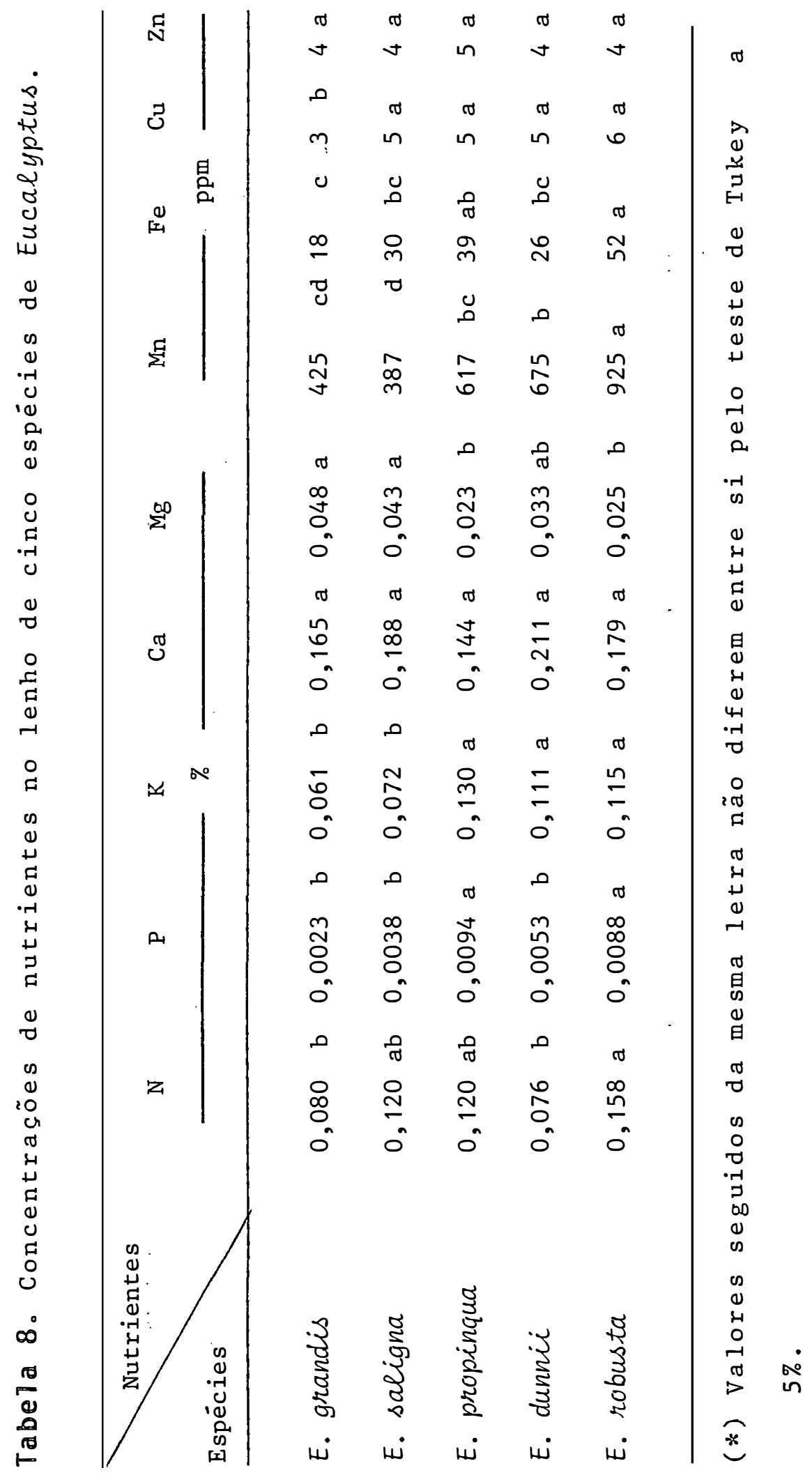


de Eucalyptus encontra-se na Tabela 9, onde pode ser observado que o E. dunnie é o que menos acumula nitrogênio, o E.gran dis é o que tem maior produtividade com menor acúmulo de $P$. e K e o E. robusta é o que mais acumula fósforo.

Tabela 9. Biomassa e conteúdo de nutrientes no lenho de cinco espécies de Eucalyptus.

\begin{tabular}{|c|c|c|c|c|c|c|}
\hline \multirow[t]{2}{*}{ Espécies } & \multirow{2}{*}{$\begin{array}{c}\text { Biomas. } \\
\text { t/ha }\end{array}$} & \multicolumn{5}{|c|}{ Nutrientes } \\
\hline & & $\mathrm{N}$ & $\mathrm{P}$ & $\mathrm{K}$ & $\mathrm{Ca}$ & $\mathrm{Mg}$ \\
\hline E. grandis & 160,3 & 128,2 & 3,7 & 97,8 & 264,5 & 76,9 \\
\hline E. saligna & 168,7 & 202,4 & 6,4 & 121,5 & 317,2 & 72,5 \\
\hline E. propinqua & 85,7 & 102,8 & 8,0 & 111,4 & 123,4 & 19,7 \\
\hline E. dunnie & 125,6 & 95,5 & 6,7 & 199,4 & 265,0 & 41,4 \\
\hline E. robusta & 117,4 & 185,5 & 10,3 & 135,0 & 210,1 & 29,3 \\
\hline
\end{tabular}

Na Tabela 10, analisando o conteúdo de nutrien tes na casca das árvores que compõem os talhões das cinco espécies de Eucalyptus, pode-se ressaltar que o talhão de E. grandis é o que acumula mais $N_{3} P$ e K e o que tem menor acủmu 10 de $\mathrm{Mg}$. Os demais elementos são acumulados em menores quan tidades nos talhões de $E$. robusta (N); E. dunnii (P) e E. pro 
pinqua ( $\mathrm{K}$ e $\mathrm{Ca}$ ).

Tabela 10. Biomassa e conteúdo de nutrientes na casca das cin co espécies de Eucalyptus.

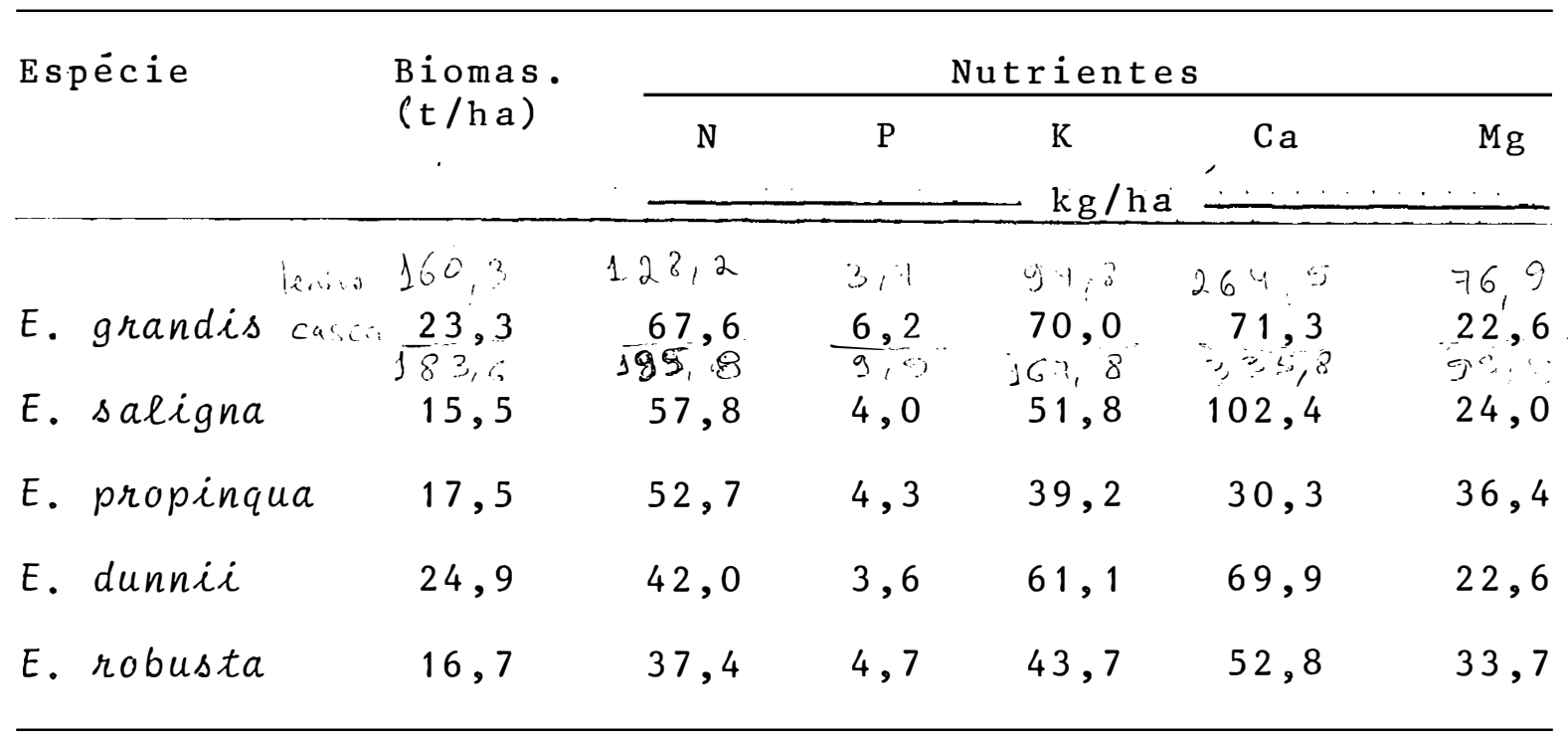

A Tabela 11, permite a comparação dos totais de biomassa e de nutrientes no tronco das cinco espécies de Eucalyptus. Observa-se que o E. saligna produz maior quantidade de biomassa e tem maiores conteúdos de nutrientes. O E. propinqua é a espécie que tem menor conteúdo de nutrientes no tronco, porém, é a menos produtiva, em termos de biomassa. 
Tabela 11. Conteúdo de N, P, K, Ca e Mg no tronco (lenho + cas ca) das cinco espécies de Eucalyptus.

\begin{tabular}{lcccc}
\hline Espécies & $\begin{array}{c}\text { Biomas } \\
\text { Tronco } \\
\text { t/ha }\end{array}$ & Lenho & $\begin{array}{c}\text { Casca } \\
\mathrm{kg} / \mathrm{ha}\end{array}$ & Tronco \\
\cline { 3 - 5 } & & & 236,6 & 897,8 \\
\hline E. grandis & 183,6 & 571,1 & 240,1 & 960,1 \\
E. saligna & 184,2 & 720,0 & 162,8 & 528,3 \\
E. propinqua & 103,2 & 365,4 & 200,1 & 748,2 \\
E. dunnii & 150,5 & 548,0 & 172,3 & 742,6 \\
E. robusta & 134,1 & 570,3 & & \\
\hline
\end{tabular}

4.7. Indice de eficiēncia de utilização dos nutrientes

0s troncos das ärvores incluem o maior percentual de biomassa produzida por uma plantação florestal. Esta proporção tende a aumentar a medida que envelhece o povoamen to (ANDRAE, 1976). O aumento desta biomassa está relacionado com a eficiência de utilização dos nutrientes por cada espécie que, segundo HANSEN e BAKER (1979), é a quantidade de matéria seca ( $\mathrm{kg}$ ) produzida por kg de nutriente utilizado.

Na Tabela 12, estão representados os indices de eficiência das cinco espécies de Eucalyptus, para a produção de biomassa do lenho. 
.40 .

Tabela 12. Indice de eficiência de utilização de nutrientes para a produção do lenho em cinco espécies de Euca lyptus.

\begin{tabular}{|c|c|c|c|c|c|}
\hline \multirow{2}{*}{ Espécie } & \multicolumn{5}{|c|}{ kg de biomasialkg de nutriente utilizado } \\
\hline & $\mathrm{N}$ & $\mathrm{P}$ & K & $\mathrm{Ca}$ & $\mathrm{Mg}$ \\
\hline E. grandis & 1250 & 43441 & 1639 & 606 & 2083 \\
\hline E. saligna & 833 & 26318 & 1389 & 532 & 2326 \\
\hline E. propinqua & 833 & 10645 & 769 & 694 & 4348 \\
\hline E. dunnie & 1316 & 18858 & 901 & 474 & 3030 \\
\hline E. robusta & 633 & 11365 & 869 & 559 & 4000 \\
\hline & & & , & . & \\
\hline
\end{tabular}

Observa-se que a espécie mais eficiente para utilização de N-é o E. dunnie, para o $\mathrm{P}$ é o E. grandis e para - Ca e Mg é o E. propinqua.

0s. Indices de eficiência, para a produção da casca, estão representados na Tabela 13, onde se observa que - E. dunnie tem destacadamente alta eficiência de utilização de $\mathrm{N}, \mathrm{P}$ e $\mathrm{Mg}$ e o E. propinqua alta eficiēncia de utilização de $\mathrm{K}$ e $\mathrm{Ca}$. 
Tabela 13. Indice de eficiência de utilização de nutrientes para a produção de casca em cinco espécies de Eucáa eyptus.

\begin{tabular}{|c|c|c|c|c|c|}
\hline \multirow{2}{*}{ Espëcie } & \multicolumn{5}{|c|}{$\begin{array}{l}\mathrm{kg} \text { de biomassa produzida/ } \\
\mathrm{kg} \text { de nutriente utilizado }\end{array}$} \\
\hline & $\mathrm{N}$ & $\mathrm{P}$ & $\mathrm{K}$ & $\mathrm{Ca}$ & $\mathrm{Mg}$ \\
\hline E. grandis & 345 & 3776 & 333 & 327 & 1031 \\
\hline E. saligna & 268 & 3846 & 299 & 151 & 426 \\
\hline E. propinqua & 332 & 4070 & 446 & 578 & 729 \\
\hline E. dunnie & 580 & 6878 & 408 & 356 & 1099 \\
\hline E. robusta & 446 & 3584 & 382 & 316 & 495 \\
\hline
\end{tabular}

Na Tabela 14, são apresentados os índices de eficiência para produção de biomassa no tronco (1enho + casca), e destaca-se como mais eficiente para utilização de nitrogēnio o E. dunnie, para utilização de fósforo e potássio o E. grandis e para utilização de cálcio e magnésio o E. propin qua. 
Tabela 14. Indice de eficiência para produção de biomassa no tronco (lenho + casca) das cinco espécies de Eucaeyptus.

\begin{tabular}{|c|c|c|c|c|c|}
\hline \multirow{2}{*}{ Espēcie } & \multicolumn{5}{|c|}{$\begin{array}{l}\mathrm{kg} \text { de biomassa produzida/ } \\
\mathrm{kg} \text { de nutriente utilizado }\end{array}$} \\
\hline & $\mathrm{N}$ & $\mathrm{P}$ & $\mathrm{K}$ & $\mathrm{Ca}$ & $\mathrm{Mn}$ \\
\hline E. grandis & 1595 & 47217 & 1972 & 933 & 3114 \\
\hline E. saligna & 1101 & 30164 & 1688 & 683 & 2752 \\
\hline E. propinqua & 1165 & 14715 & 1215 & 1272 & 5077 \\
\hline E. dunnie & 1896 & 25736 & -1309 & 830 & 4129 \\
\hline E. robusta & 1079 & 14948 & 1251 & 875 & 4485 \\
\hline
\end{tabular}

4.8. Variações das concentrações de nutrientes em função do tamanho da ārvore

Com a finalidade de se detectar variações nas concentrações de nutrientes em função do tamanho das àrvores, foram testadas diversas equações, relacionando-se parâmetros de crescimento tais como: altura (H); D (diâmetro à altura do peito) e $D^{2} \mathrm{H}$ (diâmetro a altura do peito ao quadrado $\mathrm{x}$ altu ra), em relação às concentrações de nutrientes nas folhas do àpice da copa, folhas da parte intermediäria da copa, ramos, casca e lentio. 
.43.

Dentre as equações testadas foram selecionadas como representativas aquelas que apresentaram o coeficiente de correlação mais alto, sendo que algumas se correlacionaram significativamente apenas para o diāmetro, outras para a alt ra e outra para $D^{2} \mathrm{H}$.

4.8.1. Nitrogēnio

Nas Figuras $3,4,5$ e 6 podem ser visualizadas as tendências das concentrações de nitrogênio nos ramos, lenho e casca de E. grandis, E. dunnii e. E. propinqua. observa-se que o nitrogênio apresenta concentrações mais elevadas nas ärvores dominadas. As concentrações diminuem a medida que aumenta o tamanho das árvores. 


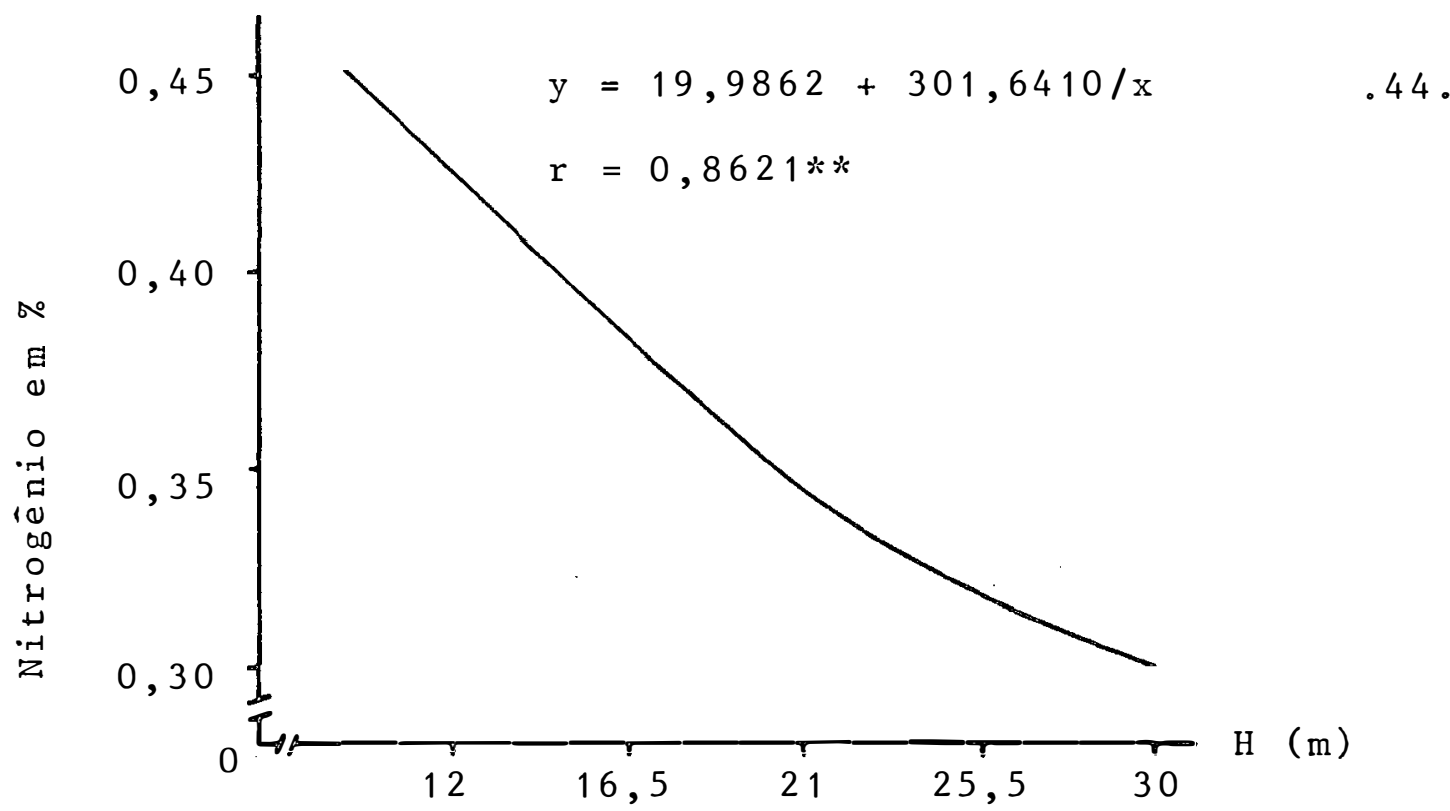

Figura 3. Representação gräfica da equação de regressão da a 1 tura versus concentração de nitrogênio nos ramos de E. grandis.

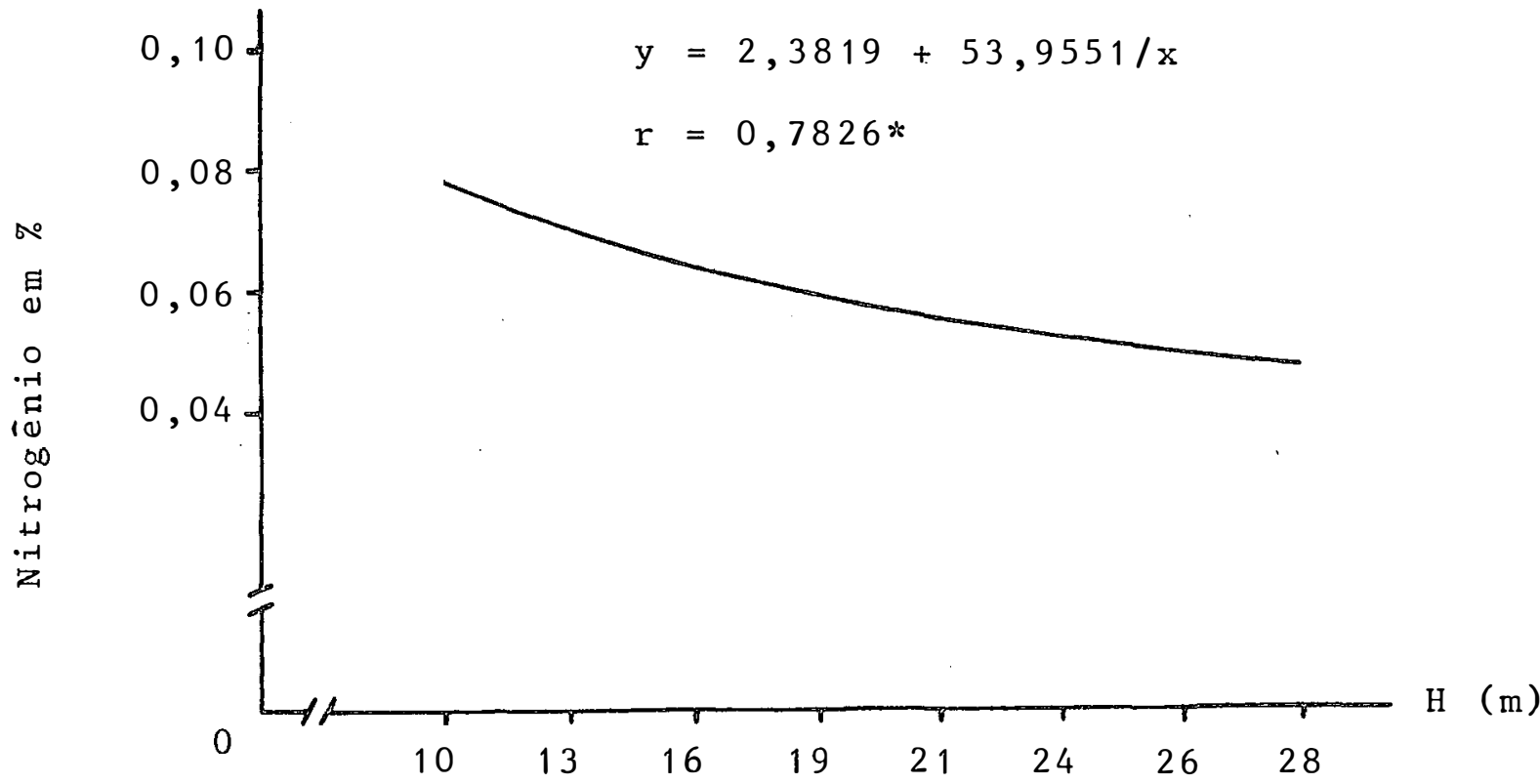

Figura 4. Representação gräfica da equação de regressão da a tura versus concentração de nitrogênio no lenho de E. dunnii. 


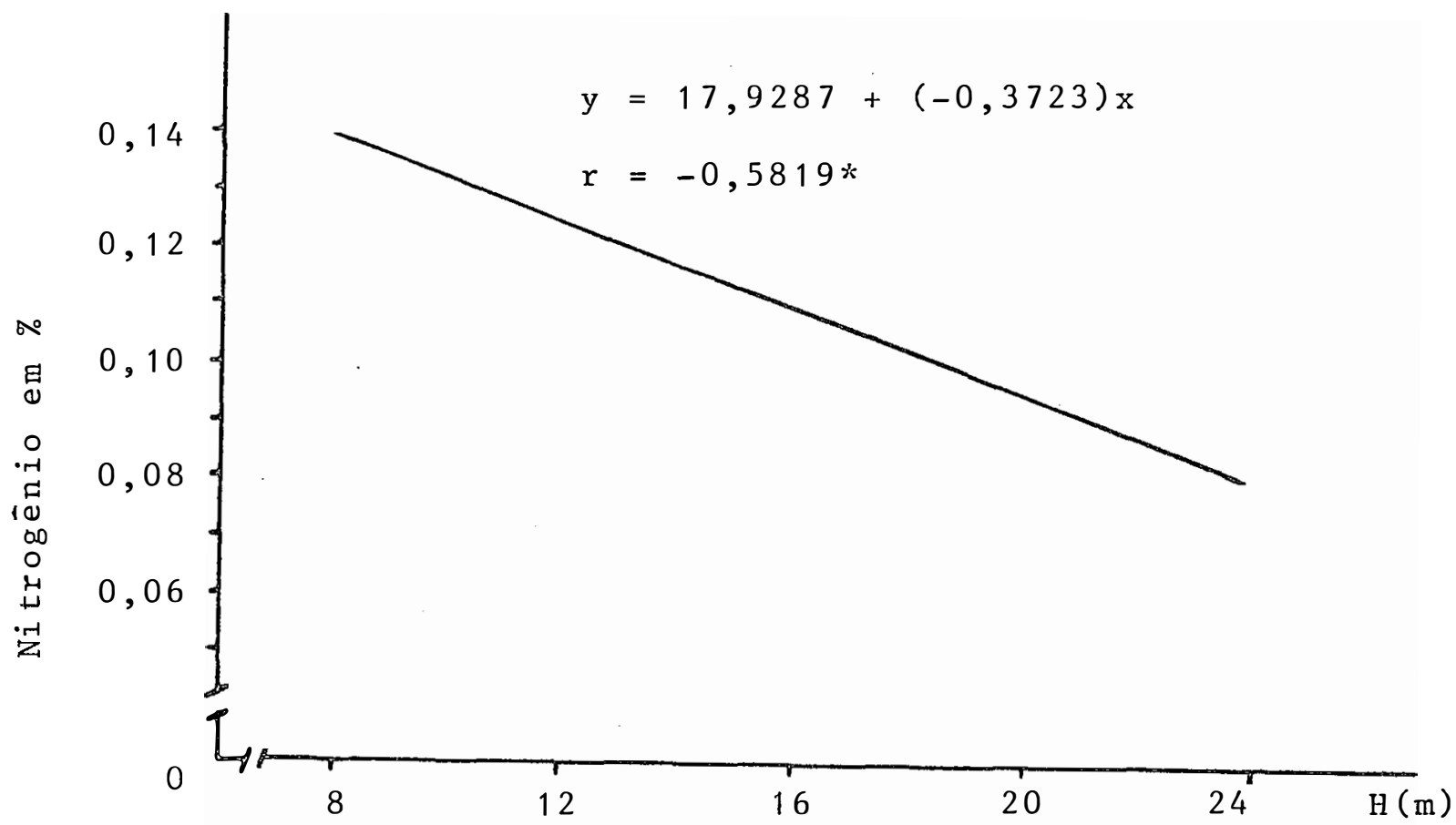

Figura 5. Representação gráfica da equação de regressão da a 1 tura versus concentração de nitrogēnio no lenho de E. propinqua.

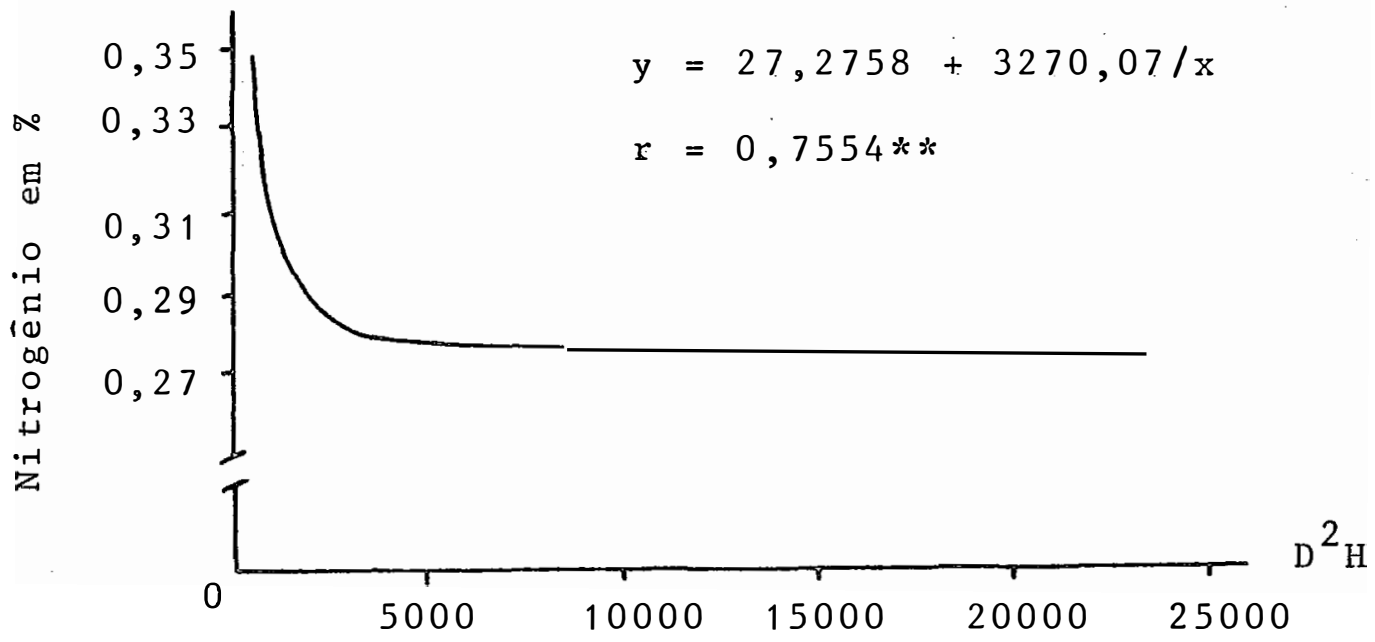

Figura 6. Representação gräfica da equação de regressão do $D^{2} H$ versus concentração de nitrogēnio na casca de E. grandis. 
4.8.2. Fósforo

As concentrações de fósforo nas folhas da parte intermediäria da copa e ramos, de $E$. grandis e $E$. saligna apresentam tendências que podem ser observadas nas Figuras 7, 8 e 9. Observa-se que o fósforo tem concentrações que aumentam com o tamanho das árvores. Entretanto, a concentração de fósforo, no lenho de E. grandis, diminui como aumento do tamanho das árvores.

4.8.3. Potássio

No lenho de E. grandis e nas folhas de ápice da copa de E. propinqua (Figuras 11 e 12 ) observa-se que as maiores concentrações de potássio encontram-se nas árvores do minadas de decrescem a medida que as ärvores apresentam um porte maior. 


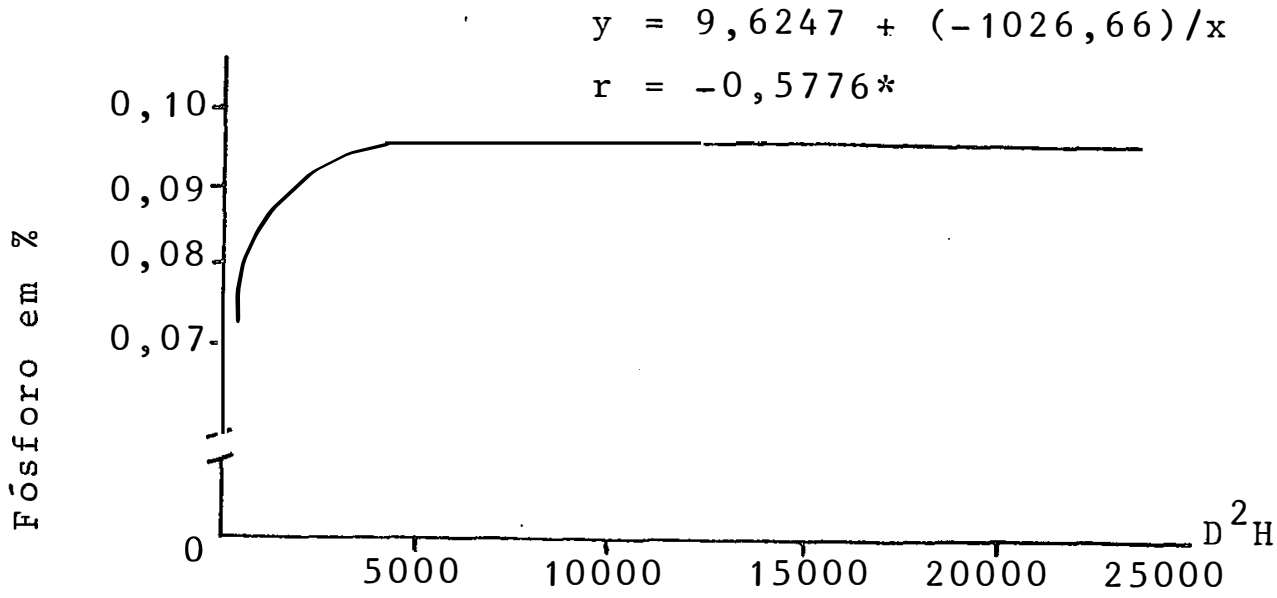

Figura 7. Representação gräfica da equação de regressão do $\mathrm{D}^{2} \mathrm{H}$ versus concentração de fösforo nas folhas d a parte intermediária da copa de E. grandis.

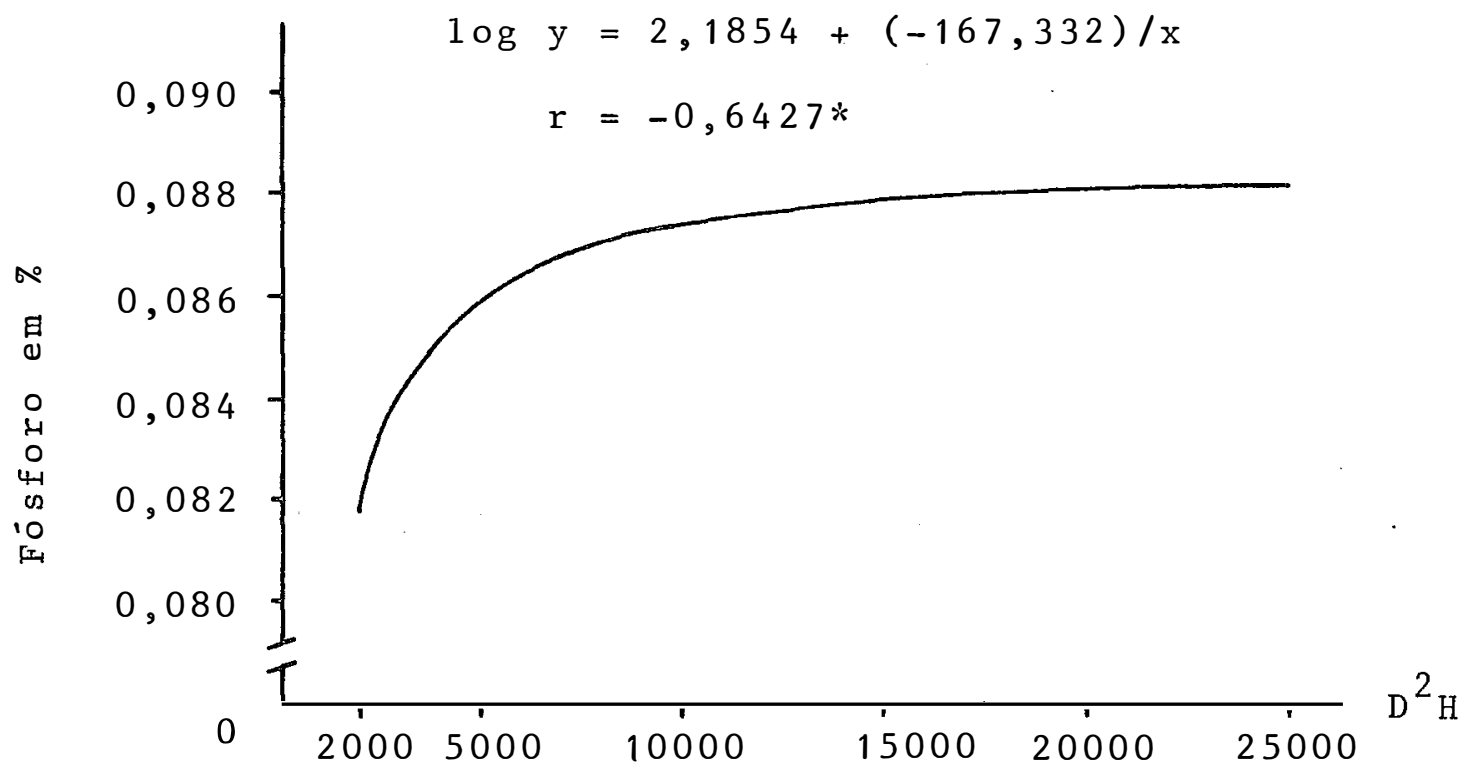

Figura 8. Representação gräfica da equação de regressão do $D^{2} \mathrm{H}$ versus concentração de fósforo das folhas da parte intermediária da copa de E. saligna. 


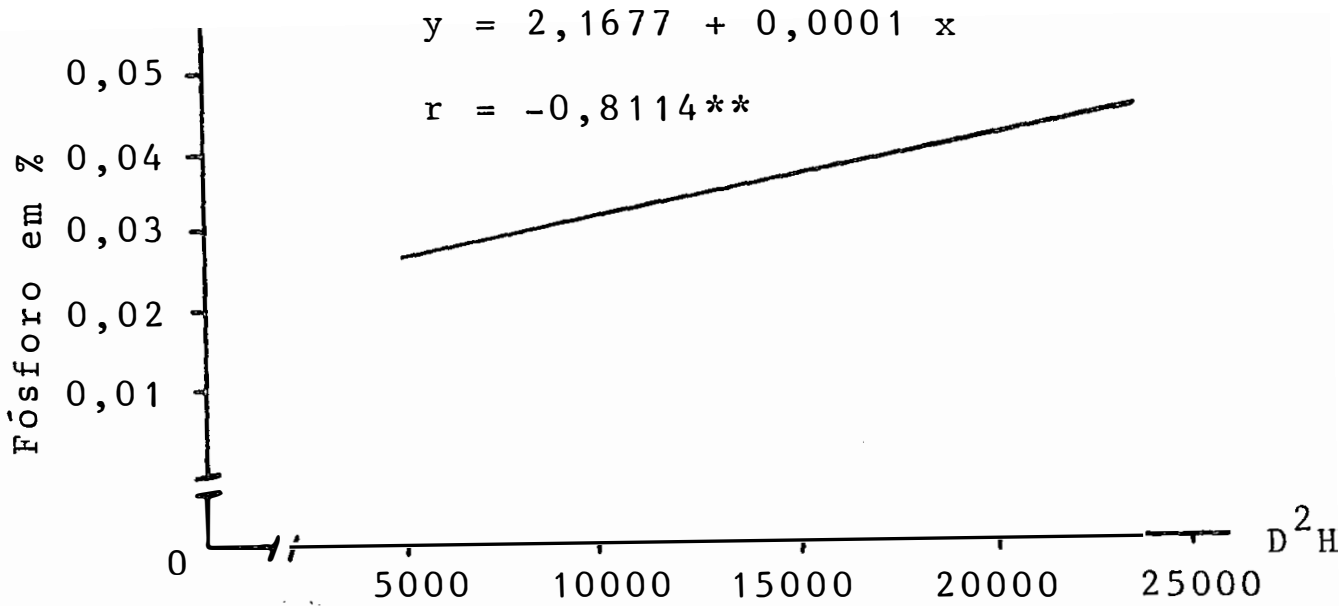

Figura 9. Representação gráfica da equação de regressão do $D^{2} \mathrm{H}$ versus concentração de fósforo nos ramos de $E$. grandis.

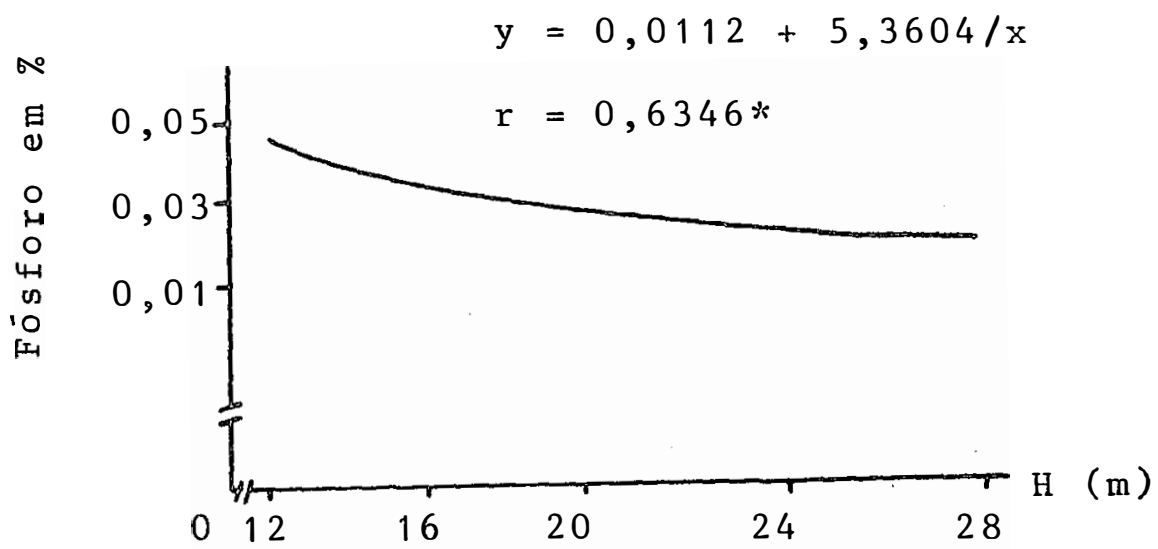

Figura 10. Representação gráfica da equação de regressão da a ltura versus concentração de fósforo no lenho de E. grandis. 


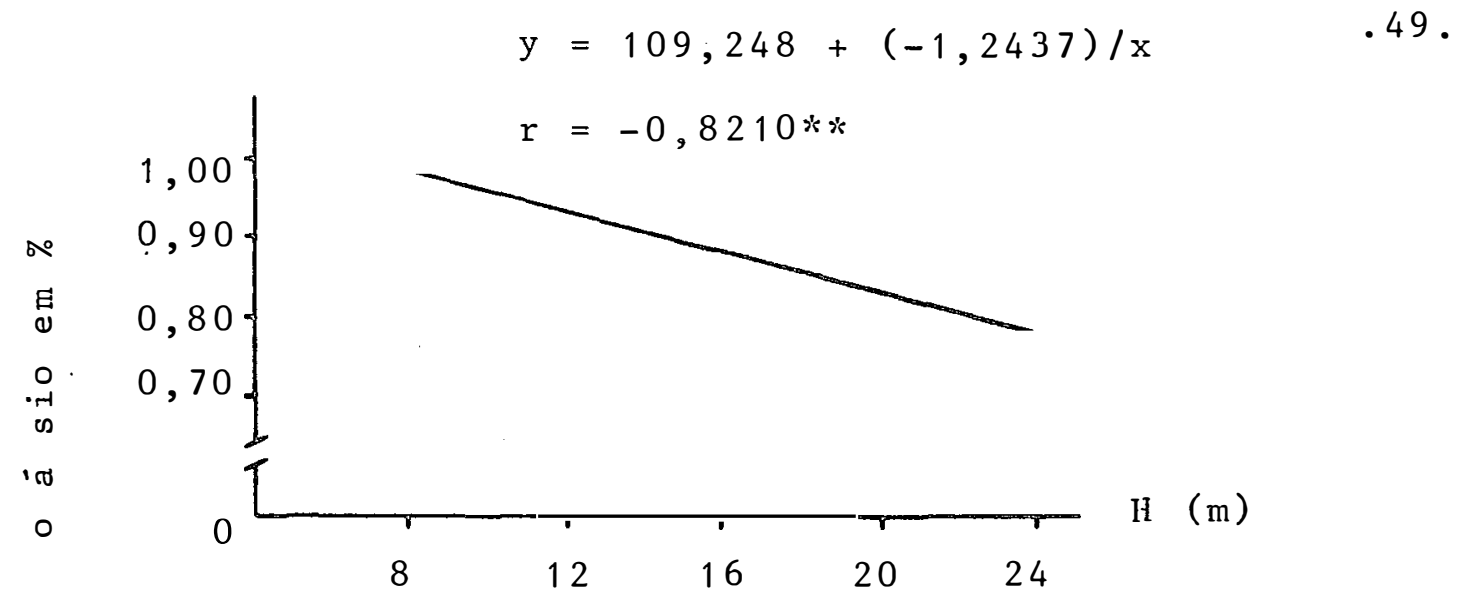

Figura 11. Representação gráfica da equação de regressão da altura versus concentração de potássio nas folhas do ápice da copa de E. propinqua.

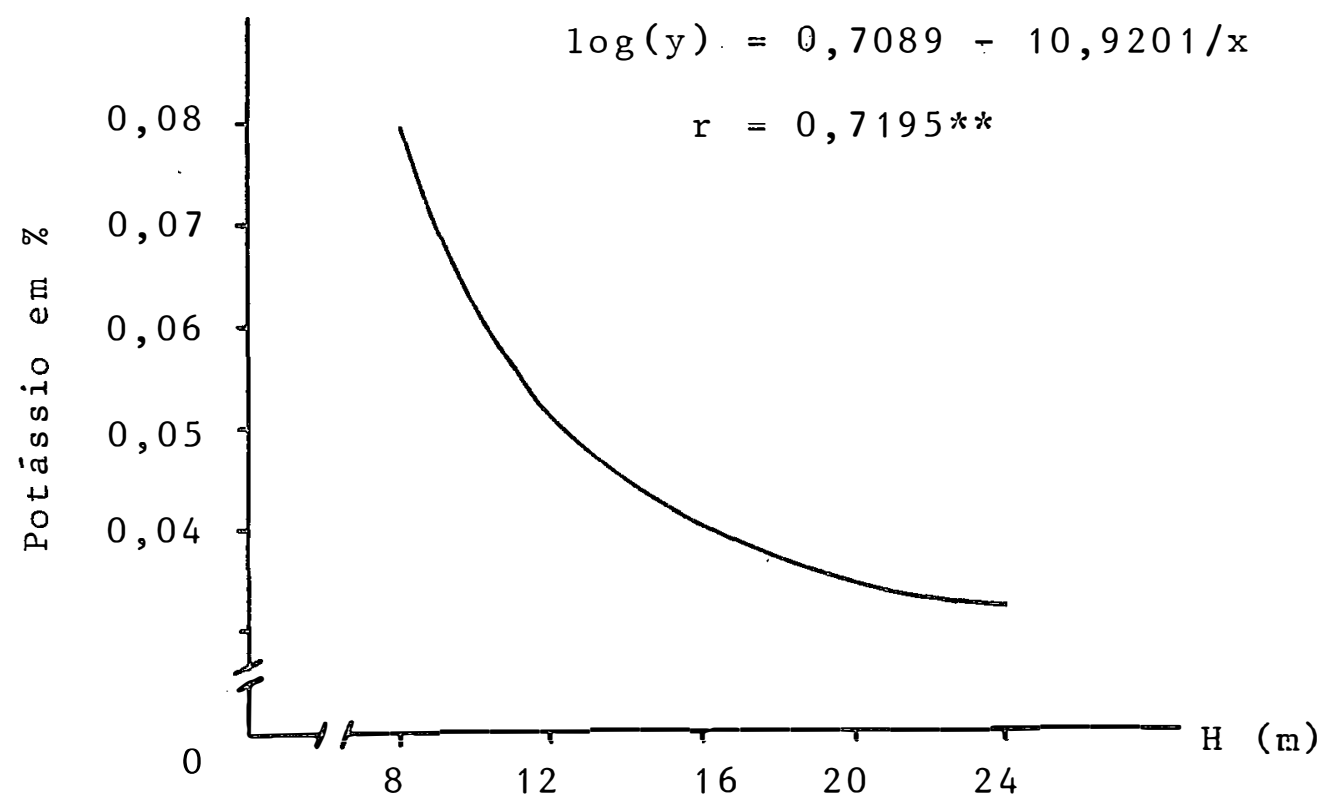

Figura 12. Representação gráfica da equação de regressão da altura versus concentração de potássio no lenho de E. grandis. 
4.8.4. Cálcio

As tendēncias das concentrações de cálcio nas fòlhas do ápice da copa de E. saligna, nas folhas da parte in termediária da copa de $E$. dunnii e na casca de $E$. saligna são apresentadas nas Figuras 13, 14 e 15 . Observa-se que na cas ca de E. saligna as concentrações de cálcio são mais altas nas ärvores de maior porte. Entretanto, nas folhas do ápice de E. saligna e nas folhas da parte intermediária de E. dunnii as concentrações de cálcio diminuem com o aumento do tama nho das ärvores.

4.8.5. Magnēsio

Nas Figuras 16 e 17 observa-se que nos ramos de E. propinqua e no lenho de E. robusta o elemento magnésio concentra-se mais nas ärvores dominantes. 


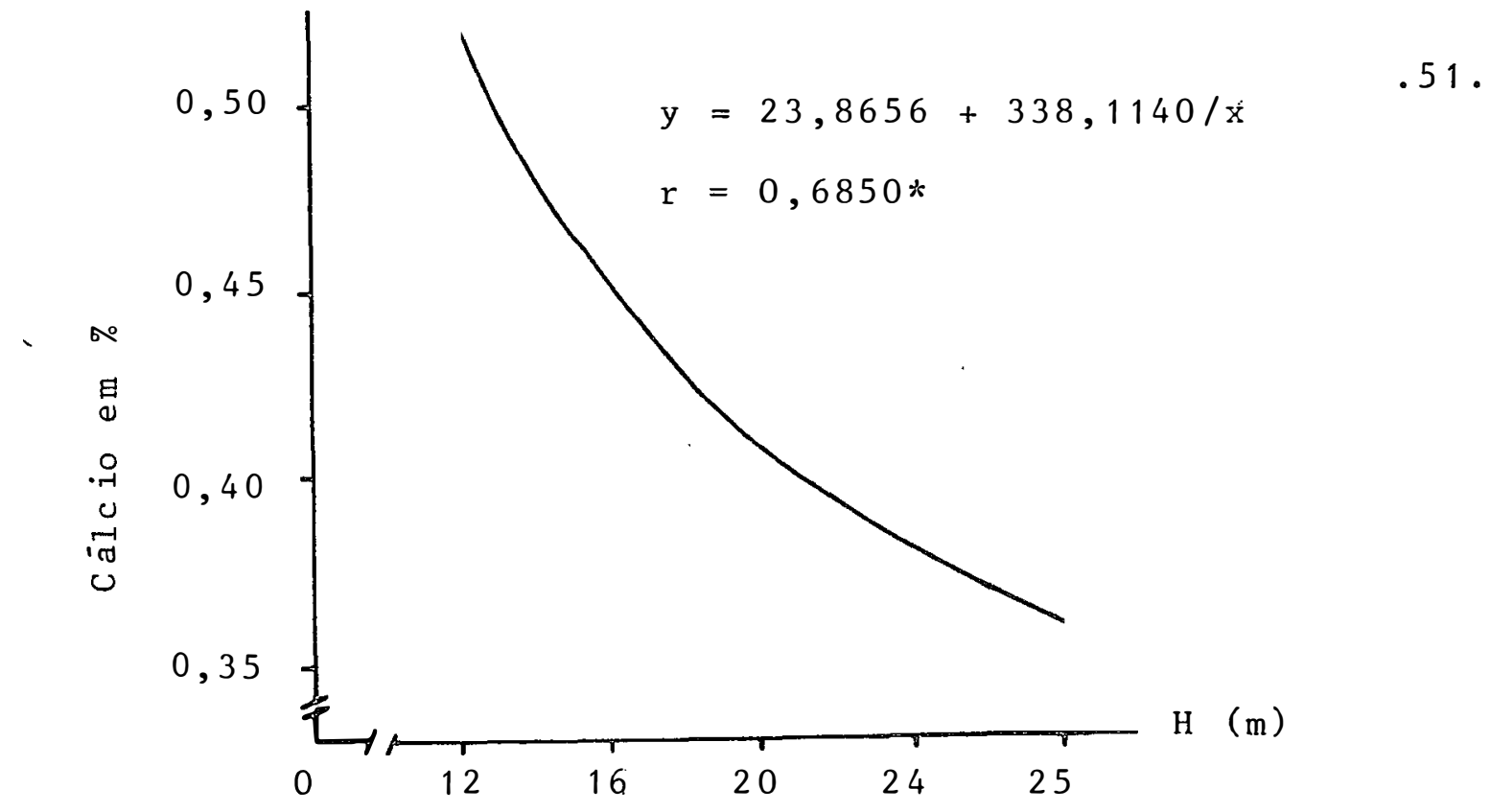

Figura 13. Representação gráfica da equação de regressão da altura versus concentração de cálcio nas folhas do ápice da copa de E. saligna.

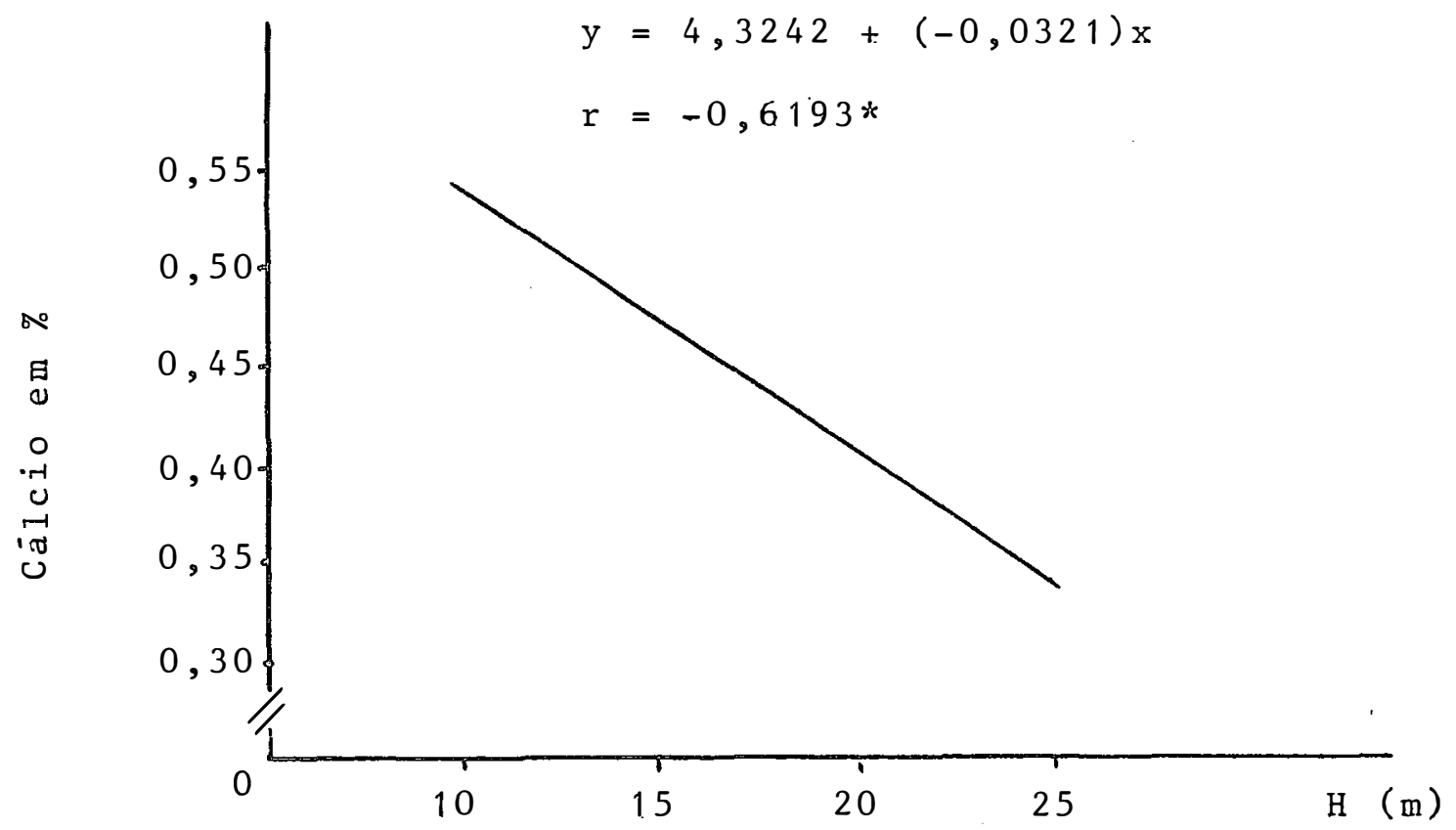

Figura 14. Representação gräfica da equação de regressão da altura versus concentração de cálcio nas folhas da parte intermediária da copa de E. dunnii. 


$$
\begin{aligned}
\log \mathrm{y} & =5,3394+(-17,7759) / \mathrm{x} \\
\mathrm{r} & =-0,7075 * *
\end{aligned}
$$

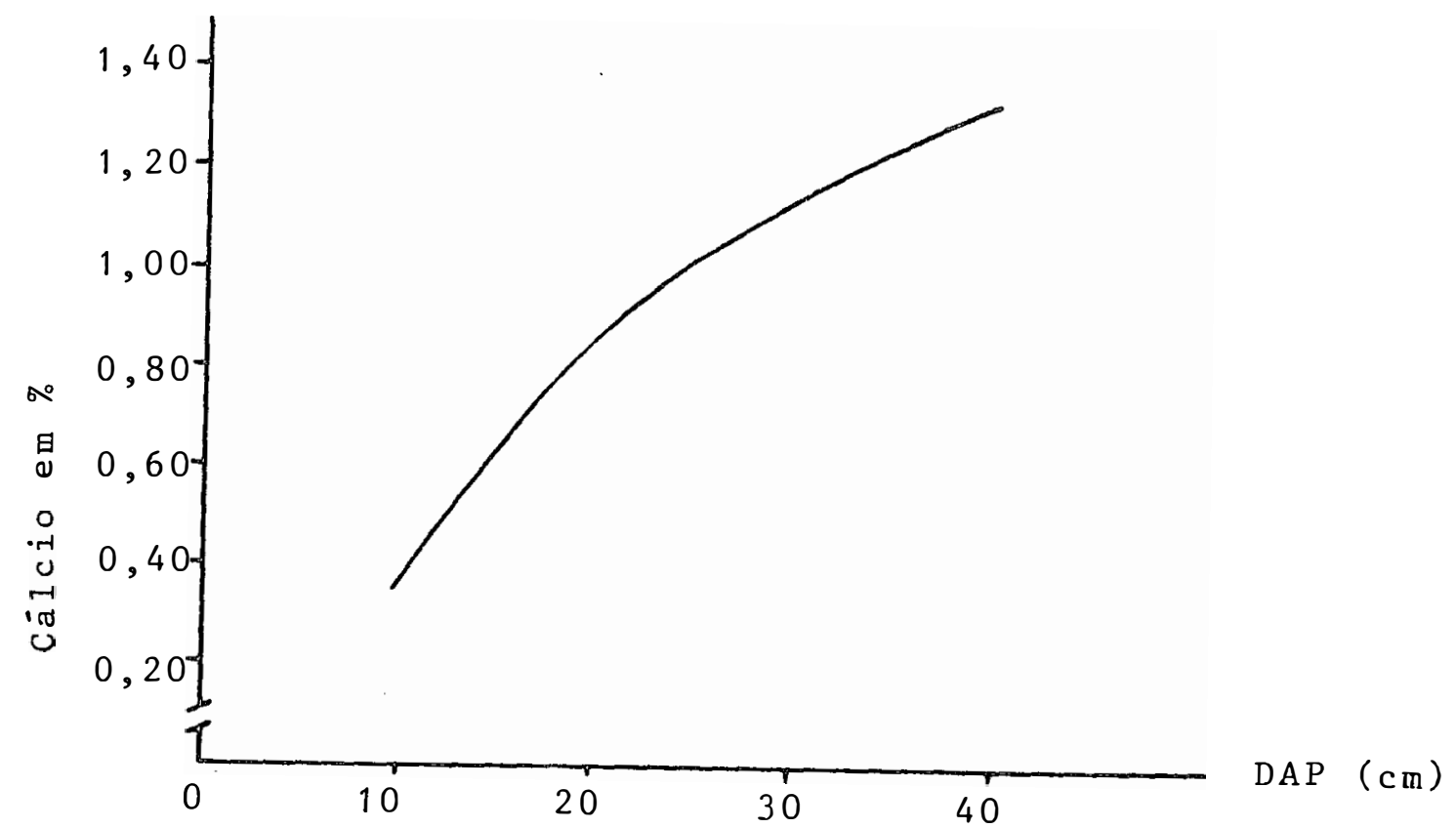

Figura 15. Representação gráfica da equação de regressão do DAP versus concentração de cälcio na casca de E. saligna. 


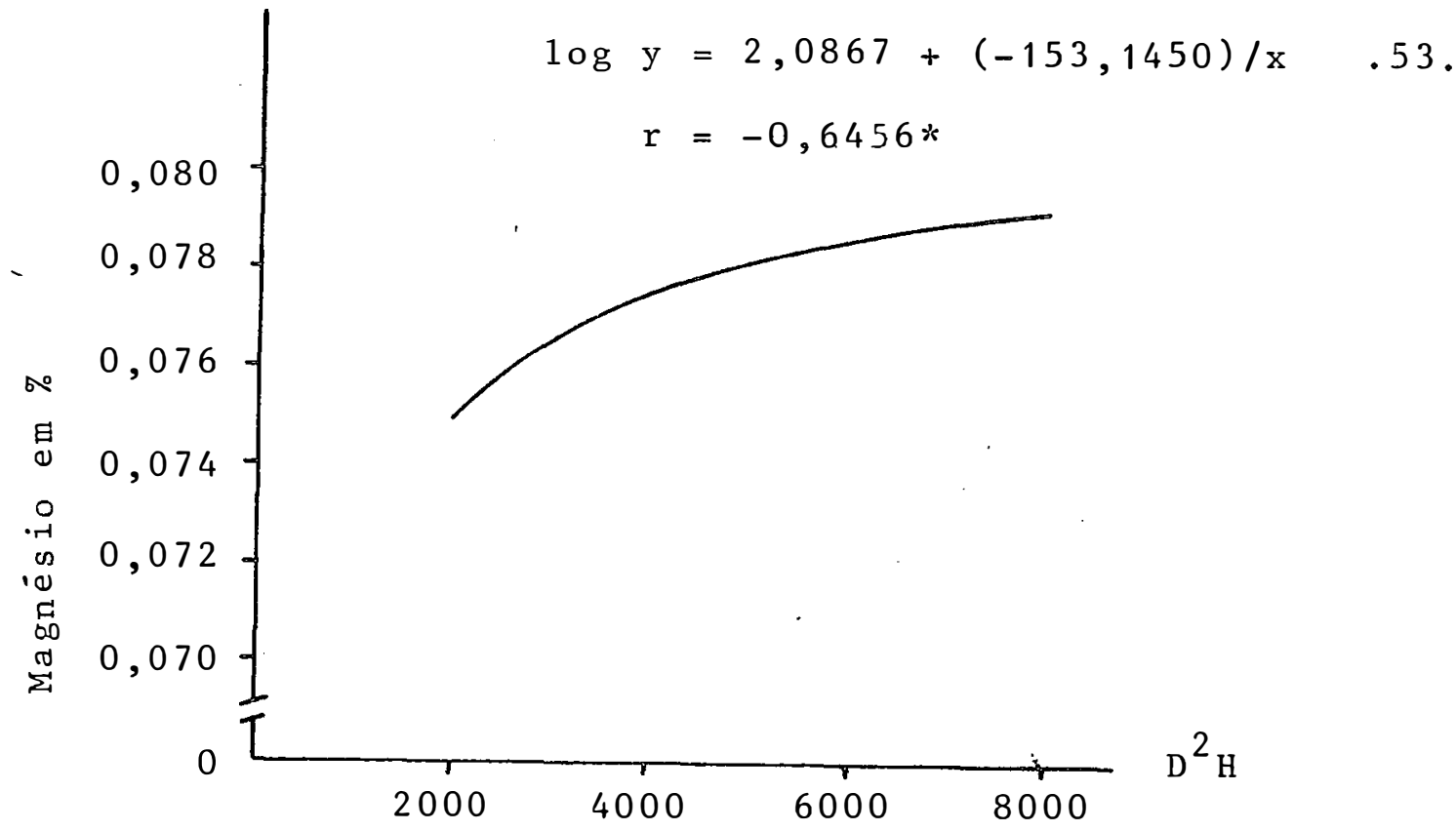

Figura 16. Representação gráfica da equação de regressão de $\mathrm{D}^{2} \mathrm{H}$ versus concentração de magnésio nos ramos de E. propinqua.

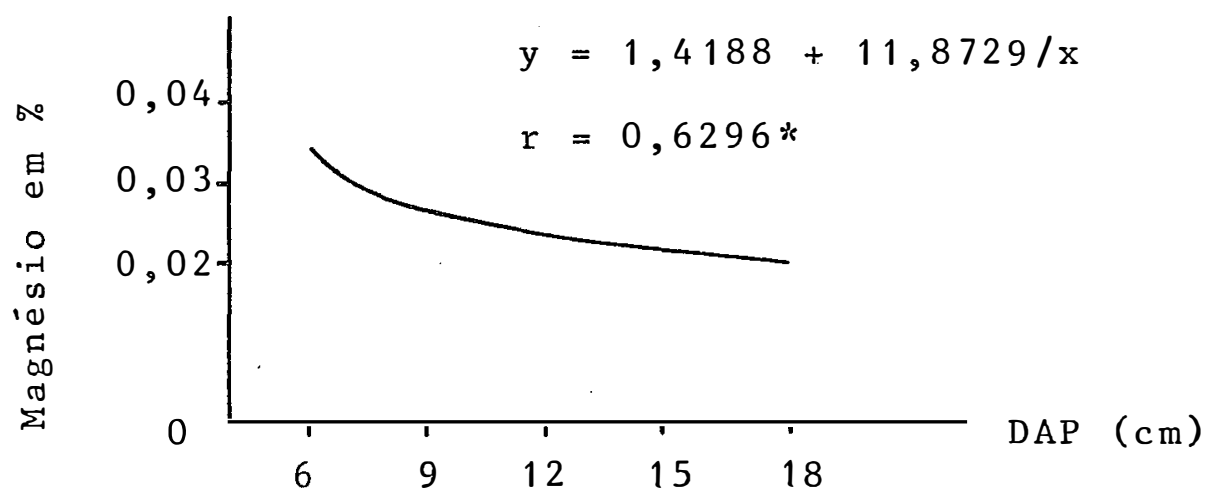

Figura 17. Representação gráfica da equação de regressão do DAP versus concentração de magnésio no lenho de $E$. robusta. 
.54 .

\section{DISCUSSAOO}

5.1. Caracterīsticas dendrométricas

Além do potencial genético que cada espécie apresenta para o crescimento, de um modo geral, os eucaliptos possuem capacidade de desenvolvimento em diversas condições de climas e solos, demonstrando uma grande plasticidade do gênero (FIERROS e MUSALEM, 1978).

o Brasil e a Austrālia têm äreas situadas dentro da mesma faixa de latitude, abrangendo condições climáticas que variam do tropical ao sub-tropical. Esta semelhança faz com que seja facilitada a introdução, no Brasil, de eucaliptos apropriados para a formação de plantações florestais.

Na Auträlia, as äreas de ocorrência das espêcies utilizadas nesta pesquisa, apresentam latitudes variando 
de 27 a $36^{\circ} \mathrm{S}$ (HALL et a $i i i, 1970$ ), abrangendo uma faixa de 1ati tude situada mais ao sul do que Itirapina, localizada a $22^{\circ} 15^{\prime}$ S e numa altitude de $760 \mathrm{~m}$. As procedências em estudo (Tabela 1) ocorrem entre $28^{\circ} 52^{\prime}$ e $31^{\circ} 54^{\prime} \mathrm{s}$ e dentre elas, o E. saligna e o E. grandis possuem na Austrāila maior distribuição geogräfica do que o E. propinqua e o E. hobusta, os quais se distri buem na faixa litorânea, enquanto que, o E. dunnì tem sua ārea de ocorrência natural mais restrita, entre $29^{\circ}$ e $31^{\circ} \mathrm{s}$ e em $10^{-}$ cais de maior altitude.

Do ponto de vista ecológico sabe-se que, até certo ponto, as variações de latitude podem ser compensadas pelas variações de altitude. Assim sendo, é possível que os $E$. grandis e E. saligna, cujos locais de origem na Austrália se si tuam ao sul, mais ao nỉvel do mar, tenham sua adaptação climátị ca favorecida pela maior altitude de Itirapina $(760 \mathrm{~m})$.

As espēcies de E. propinqua e E. robusta, que na Austrälia têm seus locais de origem em zonas de baixa altitu de, podem sofrer interferências no seu crèscimento, devido às maiores flutuações climäticas que ocorrem em Itirapina. Quanto ao E. dunnii, em se tratando de uma espécie de distribuição geo gräfica muito restrita e procedente de uma zona situada, na Aus trália, a $30^{\circ} 10^{\prime} \mathrm{s}, e^{\prime}$ possível que as condições ecológicas de Itirapina sejam pouco favoráveis ao seu ritmo de crescimento. 
dis e o E. saligna possuem melhor potencial para o desenvolvimento em solos pobres. Esta potencialidade também foi assinalada por ATTIWILL (1980), em estudo realizado na Austrälia com värias espēcies de Eucalyptus e por Gomes et alii ip (1980), no Brasil, que elegeram os E. grandis, E. saligna e E. dunnii como espécies promissoras para o crescimento em solos de baixa fertilidade.

Alëm da maior produtividade de biomassa observada, entre as espécies estudadas, os E. grandis e $E$. saligna tiveyam as menores percentagens de casca em relação ao E. robus ta e E. propinqua.

Os valores de densidade básica para o E. grandis $\left(0,496 \mathrm{~g} / \mathrm{m}^{3}\right)$. E. saligna $\left(0,534 \mathrm{~g} / \mathrm{cm}^{3}\right)$, E. propinqua $(0,634$ $\left.\mathrm{g} / \mathrm{cm}^{3}\right)$, E。 dunnii $\left(0,582 \mathrm{~g} / \mathrm{cm}^{3}\right)$ e $E$. robusta $\left(0,589 \mathrm{~g} / \mathrm{cm}^{3}\right)$, observada nesta pesquisa, diferem dos resultados apresentados por FOELKEL (1974). Este autor, que analisou a densidade básica a partir de cavados de árvores formadas de sementes procedentes de Rio Claro, cortadas aos sete anos de idade, assinalou os seguintes valores de densidade básica: E. grandis $\left(0,575 \mathrm{~g} / \mathrm{cm}^{3}\right)$, E. saligna $\left(0,562 \mathrm{~g} / \mathrm{cm}^{3}\right)$. E. propinqua $\left(0,643 \mathrm{~g} / \mathrm{cm}^{3}\right)$ e $E$. robus ta $\left(0,452 \mathrm{~g} / \mathrm{cm}^{3}\right)$. Esta diferença pode ser atribuída a origem genética do material aliada a fatores ambientais. 
FERREIRA e KAGEYAMA (1978), concluram que, $\stackrel{.57 \text {. }}{\text { de }}$ 5 a 7 anos de idade, o E. saligna, E. grandis, E. dunni e $E$. botryoides apresentaram densidade bāsica média muito semelhante, ficando entre $0,430 \mathrm{~g} / \mathrm{cm}^{3}$ e $0,500 \mathrm{~g} / \mathrm{cm}^{3}$. As espëcies de E. pilularis, E. resinifera, E. urophylla e E. propinqua pertencem ao grupo em que a densidade básica da madeira varia de 0,500 a $0,580 \mathrm{~g} / \mathrm{cm}^{3}$. Os E. microcorys e E. cloeziana destacam-se por possuirem densidades bāsica da madeira superiores a 0,580 $\mathrm{g} / \mathrm{cm}^{3}$.

A densidade básica da madeira de cada espécie pode ser afetada diretamente por diversos fatores como: tipo de célula, espessura da parede celular, quantidade de materiais não estruturais (FOELKEL, 1974), tamanho e posição da amostra no tronco (SOUZA et alii, 1979 e BRASIL et ali $i$, 1977).

os maiores valores de densidade bāsica foram encontrados nas espécies que apresentaram menor crescimento. Alēm de ser uma característica de comportamento particular para cada espécie, a densidade básica pode estar sendo influenciada pelo ritmo de crescimento das árvores. BRASIL (1972) verificou em talhões de E. propinqua, plantados em locais distintos, que havia uma dirença àltamente significativa na densidade bāsica da madeira. Aos cinco anos de idade, os valores de densidade bäsica foram maiores entre os talhöes que haviam apresentado um menor ritmo de crescimento. 
Devemos assinalar que, do ponto de vista ecoló gico nem sempre o crescimento volumétrico reflete a melhor adaptação às condições do habitat. Do ponto de vista silvicultural, devemos levar em consideração que a densidade básica é uma caracteristica importante que determina a qualidade da madeira.

5.2. Concentração e conteúdo de nutrientes nos diversos componentes das ärvores

As concentrações de nutrientes, nos diversos componentes das árvores, variam de espécie para espēcie e sofrem influências do solo, da umidade, da capacidade de absorção de nutrientes, da época do ano, do tipo de amostragem。 e também da parte da ärvore onde foi coletada a amostra.

Os resultados obtidos, apresentados nas Tabe1 as 4 e 5, demonstram que as folhas do.äpice, de um modo geral, 4 têm maiores concentraçóes de nutrientes do que as folhas da par te intermediária da copa, exceto para cälcio. Resultado semelhante foi detectado por Duvigneaud e Denaeyer-De Smet, citados por PRITCHETT (1979), num estudo em florestas decíduas.

Observando-se as Tabelas 5 a $8, \quad$ verifica-se que, em geral, as concentrações de nutrientes apresentam a se- 
guinte ordem decrescente: folhas do äpice da copa,folhas. da parte intermediaria da copa, ramos, casca e lenho. Este resultado esta de acordo com os observados, em florestas decíduas dos Estados Unidos。 por PRITCHETT (1979), em florestas de Plata nus occidentalis por WOOD et alii (1977) e em povoamentos florestais de E. grandis, por POGGIANI et alii (1983).

As maiores concentrações de nutrientes encontram-se na copa que é a região responsāvel por grande parte da atividade metabölica da ärvore.

A transferência dos nutrientes, entre os tecidos das ärvores, $\ddot{e}$ um processo que pode ser avaliado periodicamente. Remeyow, citado por PRITCHETT (1979), aponta para as florestas, dois tipos de ciclos de nutrientes: um externo e outro interno. 0 ciclo externo ou geoquímico é aquele que envolve as transferências de nutrientes para dentro e para fora do ecossistema florestal. 0 ciclo interno ou biológico é aquele que abrange a ciclagem interna dos nutrientes no ecosistema. SWITZER e NELSON (1972) propuseram que o ciclo biológico fosse dividido em duas partes: o ciclo bioquímico, que se refere à mo vimentação dos nutrientes dentro da pröpria árvore e o ciclo biogeoquímico, que abranje a ciclagem de nutrientes entre o so10 e a biomassa arbörea.

As variações nas concentrações de nutrientes. que ocorrem nas diversas partes da planta, podem ser devidas às 
transferências que se processam entre os diferentes tecidos. Os nutrientes absorvidos pelas plantas podem ser devolvidos ao so1o através da queda fo folhedo ou transferidos internamente, permanecendo na ărvore por perỉodos mais prolongados. Duvigneaud e Denaeyer-De Smet, citados por PRITCHETT (1979), demonstraram que em florestas decỉduas, durante o ciclo vegetativo。 havia uma variação nas concentrações de cálcio e potássio na seiva do xilema, sugerindo uma translocação que em geral ocorria dos tecidos senescentes para as regiões de crescimento.

SWITZER e NELSON (1972) ressaltam que 25 a $39 \%$ do nitrogênio requerido por uma plantação de Pinus, de idade en tre 17 a 20 anos, é fornecida pela ciclagem interna. Através de estudos realizados com folhas de maçã, 01 and, citado por KRA MER e KOZLOWSKI (1979), estimou que, nas 3 ou 4 semanas antes da abcisão, as folhas perderam $16 \%$ de matéria seca, $52 \%$ de nitrogênio, $27 \%$ de fósforo e $37 \%$ de potässio. A concentração de magnésio permaneceu a mesma e a de cälcio aumentou. Grigal, citado por KRAMER e KOZLOWSKI (1979), verificou em cinco espécies decíduas, que as concentrações do nitrogênio, fösforo e potassio decresceram nas folhas durante o outono, ao passo que aumentaram nos ramos. Nestas espécies, o cälcio aumentou em to dos os componentes e a concentração de magnésio foi variável.

Devido à natureza conservadora dos ciclos de nutrientes, os povoamentos florestais maduros necessitam uma de 
manda relativamente pequena de elementos do solo para o. seu crescimento (PRITCHETT, 1979).

o aumento da biomassa, geralmente, provoca tam bẻm um acúmulo de nutrientes e os dados apresentados nas Tabelas 9 e 10 demonstram que uma grande quantidade de nitrogênio, potássio e câlcio è armazenada na casca e no lenho dos eucaliptos. Na Tabela 11 , observa-se que as árvores de E. grandis e E. saligna, as espëcies que tiveram maior crescimento, também apresentam no tronco conteüdo de nutrientes $18 \%$ maior do que $E$. dunnii e E. robusta e aproximadamente 50\% maior do que $E$. propinqua.

A potencialidade que algumas espécies de euca1iptos apresentam para se desenvolverem em solos pobres, reflete uma alta capacidade de utilização de nutrientes, notadamente o elemento fösforo. 0 conte $\vec{d}$ o diferenciado de nutrientes nas diversas partes das plantas, se reflete na quantidade de nutrientes exportados por ocasião da exploração florestal.

Um programa florestal prevê o plantio de ärvores com grande potencial de crescimento e a exploração em rotações curtas. A diminuição do ciclo da rotação e a exploração das outras partes das plantas, alëm do tronco, aumentam consideravelmente a taxa de nutrientes que são removidos do $\quad$ sítio: A anālise de solo do local onde foram implantados os talhões utilizados nesta pesquisa, evidenciou uma fertilidade muito 
baixa (vide Tabela 2). No entanto, todas espēcies de eucaliptos apresentaram alta produtividade。 quando comparadas com a ve getação autóctone.

Este fato leva a crer que, os eucaliptos possuam um sistema radicular capaz de explorar grandes volumes de solo, e devem apresentar mecanismos simbióticos de fixação de nitrogênio e de absorção de outros elementos minerais.

A elevada quantidade de nutrientes, contida na biomassa do lenho e da casca das diferentes espécies, mostra que a exploração dos talhões florestais provoca uma grande remo ção dos nutrientes do sítio. Os resultados obtidos evidenciam que a casca das árvores, que representam apenas $15 \%$ da biomassa do tronco, armazena quase $30 \%$ dos nutrientes.

Neste sentido, seria conveniente que tanto a casca como os ramos e folhas das ärvores, que possuem elevadas concentrações de elementos químicos, fossem deixadas no campo por ocasião da exploração florestal.

POGGIANI et alii (1983) estimaram que um solo de uma região de cerrado de Minas Gerais apresenta por hectare, até a profundidade de $120 \mathrm{~cm}$ 。 as seguintes quantidades de elementos químicos disponíveis às plantas: $33 \mathrm{~kg}$ de fósforo, 99 $\mathrm{kg}$ de potássio, $312 \mathrm{~kg}$ de cálcio e $220 \mathrm{~kg}$ de magnésio. Estes valores, se comparados com as quantidades de nutrientes conti- 
dos no lenho e na casca das diferentes espēcies de eucaliptos (Tabelas 9 e 10), evidenciam que nas plantações florestais exis te a necessidade de se manter a fertilidade do solo atravès da utilização de adubos e que as diferentes espëcies arböreas podem exportar quantidades muito variáveis de cada elemento.

Neste sentido, hä necessidade de se implementar os estudos relativos à eficiência de utilização de nutrientes por parte das diversas espécies arbóreas.

Pode-se concluir também que as rotações mais longas se tornam necessārias, a fim de "otimizar" o processo de ciclagem bioquímica e biológica, mormente em se tratando de solos de baixa fertilidade.

5.3. Indice de eficiēncia de utilização dos nutrientes

A alta produtividade dos Eucalyptus, em solos pobres, pode estar relacionada com uma grande capacidade de ut $\underline{\mathbf{i}}$ 1 ização de nutrientes. A anălise do conteúdo de nutrientes em relação à biomassa produzida fornece subsídios para o cälculo dos İndices de eficiência para produção de biomassa no lenho e na casca, das cinco espécies de Eucalyptus envolvidas neste estudo (Tabelas 12, 13 e 14). Observa-se que o fösforo $\vec{e}$ um elemento utilizado com muita eficiência, notadamente, pelo E. gra dis que produz $43.411 \mathrm{~kg}$ de biomassa/kg de nutriente (P). 
Ashton, citado por ATtiwill (1980), encontrou alto indice de eficiência dos E. regnans e E. siberi para util zação do fósforo. Estas espécies produziram respectivamente : 49.000 e $66.000 \mathrm{~kg}$ de biomassa por $\mathrm{kg}$ de fósforo acumulado. Os resultados obtidos referentes à utilização do fósforo pelas espëcies do gênero Eucalyptus confirmam as observações de ATtiWILL (1980), o qual concluiu que as florestas de eucaliptos têm baixo requerimento deste elemento.

Na Tabela 14, encontram-se os indices de eficiência para a produção de biomassa no lenho, na casca e tronco de cada espécie.

E preciso assinalar que neste caso os indices foram calculados com base na eficiência de cada um dos elementos isoladamente (conforme Tabela 12 e 13) e representados na Tabela 14 como a quantidade total de biomassa produzida por kg de cada um dos elementos: nitrogênio, fósforo, potássio, cálcio e magnèsio.

HANSEN e BAKÉR (1979) demonstraram que as ärvores mais jovens de Populus e Platanus tendem a ser menos eficientes do que as árvores mais velhas. Resultado semelhante foi observado por PogGIANI (1983), quando comparou o indice de eficiência entre talhões de $E_{i}$ saligna, $E_{\text {. grandis e Pinus }}$ oocarpa, em diferentes idades. 
.65 .

Tabela 14. Indice de eficiência para produção de biomassa no le nho, casca e tronco em cinco espëcies de Eucalyptus.

Espëcie

$\therefore$ Indice de eficiência

Lenho C...Casca Tronco

E. grandis

49019

5812

54831

E. saligna

31399

4990

36389

E. propinqua

16989

6155

23444

E. dunnii

24579

9321

33900

E. robusta

17426

5223

22639

Os dados apresentados na Tabela 14 permitem comparações entre as cinco espécies de eucaliptos estudadas. Aos 10 anos de idade, os resultados destacam o E. grandis como a mais eficiente, produzindo $34 \%$ a mais de biomassa e utilizando $15 \%$ a menos de nutrientes quando comparado com o $E$. saligna que é a segunda espécie em termos de eficiência de utilização de nutrientes. Dentre as espëcies estudadas, o E. grandis seria, portanto, a melhor opção para plantios em solos pobres, no tadamente。 em fösforo e potássio.

HANSEN e BAKER (1979) justificaram que a baixa eficiência das plantas jovens de Populus e Platanus deve-se à grande produção de ramos e casca, componentes das ärvores que possuem altas concentrações de nutrientes. Zavitkovoski et 
ali $i$ citados por HANSEN e BAKER (1979), verificaram que, com o aumento da idade da ärvore, a proporção de ramos e casca decres ce e hä um aumento significativo na biomassa do lenho.

Estas considerações deixam claro que som a expansão da silvicultura para regiões de solos de baixa fertili dade, será preciso aprofundar os estudos quanto à escolha corre ta de espëcies que tenham maior İndice de eficiência de utiliza ção de nutrientes.

5.4. Variação na concentração de nutrientes em função do tamanho das ārvores

As comparações das concentrações de nutrientes em talhões, onde existem ärvores de diferentes tamanhos, não è um assumto amplamente estudado e normalmente, quando abordado, as comparações são feitas entre árvores de idades diferentes.

Arvores de mesma idade e plantadas em povoamentos puros apresentam ao longo do tempo tamanhos diferentes, que podem relacionar-se ou não com o conteủdo de nutrientes nos diferentes tecidos vegetais. Estas variações podem ser justif cadas por vários fatores, tais como: mobilidade do nutriente nos tecidos, estägio de crescimento, efeito de diluição, espaça mento disponível e variações na fertilidade do solo. 
Deve-se considerar todavia, que as correlações entre os teores de nutrientes e tamanho das ärvores, devido a fatores inerentes a metodologia empregada e ao nümero de ă $\underline{\underline{r}}$ vores amostradas, nem sempre apresentaram coeficientes elevados. Assim sendo, apenas aígumas equações de regressão testadas tiveram um coeficiente de correlação satisfatório e foram incluidas nos resultados.

\subsubsection{Nitrogēnio}

o nitrogênio é um elemento altamente móvel e suas concentrações nos tecidos vegetais variam com a idade, tipo de tecido, estägio de desenvolvimento e estação do ano. As mais altas concentrações do nitrogênio são encontradas nos tecidos de maior atividade fisiologica, como as folhas e os tecidos meristemäticos. E um elemento essencial na constitui ção dos aminoảcidos e proteínas, ocorrendo em uma grande variedade de compostos como as enzimas, a clorofila, as membranas celulares, etc.

As ärvores podem utilizar o nitrogênio na forma de nitratos, nitritos, sais de amônio e compostos orgânicos como a urëia. Entretanto, o nitrogênio ë absorvido na maioria das vezes na forma de nitrato ou amônio. As principais fontes do nitrogênio utilizadas pelas ärvores são aque- 
.68 .

las existentes no solo, onde este elemento é fixado diretamen te da atmosfera atravës da ação de microorganismos ou resultante da decomposição do material orgânico acumulado na serra pilheira.

Os resultados observados nas variações das con centrações de nitrogênio em função do tamanho das ärvores são representados nas Figuras ( $3,4,5$ e 6 ), onde se nota que nos ramos e casca de E. grandis e no lenho de E. dunnii e E. propinqua, o nitrogênio apresenta concentrações mais elevadas nas ärvores de menor porte.

Segundo alguns autores citados por KRAMER e KOZLOWSKI (1979), o decréscimo da concentração de nitrogênio, a medida que aumenta o tamanho da árvore, pode ser explicado pelo aumento do peso seco dos tecidos vegetais. RAIJ (1981) ressalta que um decrëscimo na concentração de nutrientes, quando aumenta a biomassa, deve-se provavelmente a um efeito de diluição, onde a quantidade de nutrientes permanece constante, mas o aumento da biomassa provoca um decréscimo na con centração.

5.4.2. Fösforo

o fösforo è um elemento constituinte das nucleoproteínas e fosfolipideos; é essencial no processo de 
.69.

transferência de energia que è vital para a vida e crescimento das plantas. Ocorre na forma orgânica e provavelmente transloca-se nas plantas em ambas as formas. E derivado primariamente do fosfato de cálcio, fosfato de aluminio e fosfato de ferro.

A disponibilidade de fósforo depende, grandemente, da acidez do solo e seus efeitos na solubilidade do ferro, aluminio e manganês; da disponibilidade de cálcio e da atividade dos microorganismos que controlam a taxa de decomposição.

E um elemento relativamente móvel nas plantas e, quando ocorre uma deficiência, ele è rapidamente transferí do dos tecidos mais velhos para aqueles de atividade meristemätica mais intensa.

Nas Figuras 7,8 e 9 observa-se as variações das concentrações de fósforo em função do tamanho das ārvores e nota-se que nas folhas da parte intermediária da copa de $E$. grandis, E. saligna e os ramos de $E$. grandis as concentrações tendem a aumentar com o tamanho das árvores. Todavia, é preciso ressaltar que o lenho de $E$. grandis (Figura 10) a concen tração diminui com o aumento da altura das árvores.

Alëm dos fatares genëticos que podem determinar a maior ou menor capacidade de absorção de fösforo pelas 
plantas, a concentração mais elevada deste elemento nas árvo res dominantes pode estar relacionada com a maior atividade metabólica e a capacidade de reciclagem interna apresentada pelas árvores de maior porte, transferindo o fósforo dos teci dos velhos para os metabolicamente mais ativos.

A tendência apresentada na Figura 11, para a concentração de fósforo no lenho de E. grandis, é provavelmen te justificada pela mobilidade deste elemento, que tem capaci dade de transferir-se rapidamente dos tecidos mais velhos para as regiões de maior atividade meristemática. O E. grandis, conforme está evidenciado na Tabela 12, apresenta um a1to Indice de eficiência de utilização de fósforo, o que, de certo modo, confirma a sua capacidade de reciclagem.

\subsubsection{Potássio}

o potässio, ao conträrio do nitrogênio, fósforo e outros elementos, aparentemente não é parte integrante do protoplasma, gorduras e outros componentes das plantas e nem $\vec{e}$ essencial para muitas funções. sendo provavelmente envolvido principalmente na atividade enzimática (PRITCHETT, 1979 e KRAMER e KOZLOWSKI, 1979). E muito utilizado nos teci dos de crescimento, principalmente nas folhas e ramos (LADIGES e ASHTON, 1977 e ANDRAE e KRAPFENBAUER, 1979). 
Origina-se primariamente dos feldspatos e micas, e existe no solo sob a forma de compostos inorgânicos. E um elemento altamente mövel nas plantas e parece ser rápido e eficientemente ciclado dentro do ecossistema florestal.

Nas Figuras 11 e 12 observa-se, nas folhas de E. propinqua e no lenho de E. grandis, que o potásio item maiores concentrações nas ärvores de menor porte. Deve ser assinalado que, o solo da região de Itirapina é extremamente pobre em potássio e consequentemente o fenômeno da ciclagem bioquímica, dentro das plantas, assume um aspecto fisiológico ainda mais importante. Desta forma, a rápida translocação deste elemento, dos tecidos mais velhos para as regiões em crescimento, torna mais evidente o fenômeno de diluição obse vado nas Figuras 11 e 12 .

\subsubsection{Cálcio}

A função específica do cálcio nas plantas é ainda pouco compreendida (PRITCHETT, 1979). Ele se envolve no desenvolvimento dos tecidos meristemáticos。 na alongação dos caules e raízes e talvez, na formação de proteínas. E um ativador de värias enzimas, incluindo a amilase. $\bar{E}$ considerado um elemento imóvel nas plantas e ocorre em consideráveis quantidades nas paredes celulares influenciando a sua 
elasticidade.

Nos solos, ocorre na forma inorgânica e geralmente, os solos situados em regiões de baixa precipitação con tẻm mais cálcio do que os solos de regiões mais ümidas. Alëm disso, os horizontes mais profundos possuem maior quantidade de cálcio do que os superficiais. O sistema radicular das ār vores é capaz de explorar os solos a grandes profundidades, retirando o cálcio das reservas mais profundas e depositando-o na superfície, através da queda do folhedo (PRICHETT, 1979)。

Nas Figuras 13。14 e 15 estão representadas as tendências das concentrações de cālcio nas folhas do āpice da copa de E. saligna e E. dunnii, e na casca de E. saligna. ob serva-se que, nas folhas do ápice da copa, as concentrações são maiores nas árvores dominadas. Como se trata de um elemento praticamente imóvel, o aumento da biomassa foliar com a diminuição da concentração do cálcio, sugere um efeito de di1 uição.

Por outro 1ado, na Figura 15, nota-se que casca de E. saligna possui maiores concentrações nas ärvores com diâmetro mais desenvolvidos. Sabe-se que o cálcio tem pouca mobilidade e os eucaliptos são ärvores que acumulam gran des quantidades deste elemento (Tabelas 9 e 10). Deve-se assinalar que o E. saligna é altamente acumulador de cālcio na 
casca. Isto sugere que a ciclagem bioquímica do cálcio deve ser prejudicada. Este fato poderia explicar a diminuição na concentração de călcio observada nas folhas do äpice da copa das ärvores dominantes.

\subsubsection{Magnësio}

o magnésio é o ünico mineral constituinte da molécula de clorofila e é essencial para a fotossíntese. $\bar{E}$ fi um elemento extremamente móvel, que pode se deslocar dos teci dos velhos para as partes mais novas das plantas.

Nas Figuras 16 e 17 , observa-se nos ramos de E. propinqua e no lenho de E. robusta respectivamente um acrëscimo e um decrëscimo na concentração deste constituinte em função do tamanho das árvores. A diminuição no lenho das ărvores dominantes pode estar ligada à alta capacidade de reciclagem deste elemento. A alta concentração de magnésio encontrada nas folhas do äpice da copa e a baixa concentração observada no lenho, para todas as espécies de eucaliptos, reforça a idêia da importância que o fenômero da ciclagem interna de nutrientes representa para as espécies arbóreas e no tadamente, para aquelas de räpido crescimento. 


\section{CONCLUSÕES E RECOMENDAÇÕES}

1. As espécies de Eucalyptus estudadas demons tram os seguintes niveis de produtividade aos 10 anos de idade: E. grandis $\left(379 \mathrm{~m}^{3} / \mathrm{ha}\right)$; E. saligna $\left(372 \mathrm{~m}^{3} / \mathrm{ha}\right)$; E. robus ta $\left(273 \mathrm{~m}^{3} / \mathrm{ha}\right)$; E. dunnii $\left(266 \mathrm{~m}^{3} / \mathrm{ha}\right)$ e $E$. propinqua $\left(186 \mathrm{~m}^{3} /\right.$ ha).

2. Os valores de densidade básica da madeira, em ordem decrescente, foram: $E$. propinqua $\left(0,634 \mathrm{~g} / \mathrm{cm}^{3}\right)$; $E$. robusta $\left(0,589 \mathrm{~g} / \mathrm{cm}^{3}\right) ; E$. dunnii $\left(0,582 \mathrm{~g} / \mathrm{cm}^{3}\right) ; \quad E$. saligna $\left(0,534 \mathrm{~g} / \mathrm{cm}^{3}\right)$ e $E$. grandis $\left(0,496 \mathrm{~g} / \mathrm{cm}^{3}\right)$.

3. As concëntrações de nutrientes nas cinco es pécies estudadas foram maiores nas folhas do ápice da copa, a seguir em ordem decrescente, nas folhas da parte intermediária da copa, ramos, casca e lenho. 
4. 0 E. grandis é a espécie que apresentou o mais elevado indice de eficiēncia de utilização do fósforo e potàssio.

o E. grandis é a espécie mais eficiente na utị 1 ização de nutrientes; produzindo $34 \%$ a mais de biomassa e utilizando $15 \%$ a menos de nutrientes do que o $E$. saligna que e a segunda mais produtiva em termos de eficiência de utiliza çao.

o E. saligna apresenta-se como uma espécie acü muladora de cálcio na casca.

E recomendävel a adoção de rotações mais longas para otimizar o processo de ciclagem bioquímica e biológi ca, notadamente em solos de baixa fertilidade.

Há necessidade de se implantar estudos relativos à eficiência de utilização de nutrientes em espécies arbọ reas。 


\section{LITERATURA CITADA}

ANDRAE, F., 1976. Wachstum, wasser-und nahrsto Ffhaushalt von Araucaria angustifolia 0. Kuntze, Cordia trichotoma Arrab. und Eucalyptus saligna Smith. Wien, Universitat fur Bodenkultur. 140 p. (tese Doutoramento US)(Resumo em português).

ANDRAE, F. e A. KRAPFENBAUER, 1979. Untercuchungen uber biomassen-und Neahrstolffverhaeltnisse in einer vierjahigen Aufforstung mit Eucalyptus saligna Smith in Santa Maria, RS, brasilien. Centralblatt fur das Gesamte Forstwesen, Wien $\underline{96}(1): 1-29$.

ATTIWILL, P.M., 1980. Energy, nutrient flow and biomass. In: AUSTRALIAN FOREST NUTRITION WORKSPHOP PRODUCTIVITY IN PERPETUty. Proceedings, Canberra, p. 131-58.

BARTOS, D.L. e R.S. JOHSNTON, 1978. Biomass and nutrient content of quaking aspen at two sites in the Western Unites States. Forest Science, Washington 24(2):283-80. 
BATES, T.E., 1971. Factors affecting critical nutrient concentrations in plants and their evaluation: a review. Soil Science. Baltimore. '112(2): 116-30.

BELlote, A.F.I., 1979. Concentração e exportação de nutrientes pelo Eucalyptys grandis (Hill ex Maiden) em função da idade. Piracicaba, 129 p. (Tese - Mestrado - ESALQ)

BOWERSOX, T.W. e W.W. WARD, 1977a. Soil fertility, growth, and yield of young hybrid poplar plantations in Central Pennsylvania. Forest Science, Washington; 23(4): 463-9.

BOWERSOX, T.W. e W.W. WARD, 1977b. Seasonal variation in foliar nutrient concentrations of black cherry. Forest Science, Washington, 23(4): 429-32.

BRASIL, M.A.M., 1972. Variação da densidade básica da madeira de Eucalyptus propinqua Deane ex Maiden em função do local e do espaçamento. Piracicaba. (Tese - Mestrado - EsAlQ).

BRASIL, M.A., R.A. de A. VEIGA e M. FERREIRA, 1977. Variação da densidade básica nas seções transversais do caule da base do tronco para a copa de eucalipto. IPEF, Piracicaba, $(15): 73-82$. 
BURR, G.0., 1961. Growth and composition of sugar cane as influenced by nitrogen. In: RENTHER, W. Plant Analysis and Fertilization,Problems. Washington. American Institute Biological Sciences. p. 227-37.

CANNELL, G.H., K.B. TYLER e C.W. ASBELL, 1959. The effects of irrigation and fertilizers on yield, black heart and nutrient uptake of celery. Proceedings of the American Society of Horticultural Sciences; 74: 539-45.

CZAPOWSKYJ, M.M., 1979. Foliar nutrient concentrations in Balsam fir as affected by soil drainage and methods of slash disposal. Broomall, USDA, Forest Service, 4 p.

EVANS, J., 1979. The effects of leaf position and leaf age in foliar analysis of Gmelina arborea. Plant Soil, The Hague, 52(4): 547-52.

FERREIRA, M. e P.I. KAGEYAMA, 1978. Melhoramento genético da desnidade da madeira de eucalipto. Boletim Informativo. IPEF, Piracicaba, 6 (20): A-1/A-14.

FIERROS, A.M. e M.A. MUSALEM, 1978. Ensayos de introduccion del genero Eucalyptus en algunas regiones de Mexico. Cïên cia forestal, Chapingo. (19): 3-13.

FOELKEL, C.E.B., 1974. Rendimentos em cclulose sulfato de Eucalyptus spip. em função do grau de deslignificação e da densidade da madeira. IPEF, Piracicaba, (9): 61-77. 
FORREST, W.G, e J.D. OVINGTON, 1971. Variation in dry weight and mineral nutrient content of Pinus radiata progeny. Silvae Genetica, Frankfurt, 20.(5/6): 174-9).

GOMES, J.M., R.M. BRANDI, J.F. CĀNDIDO e L.M. de OLIVEIRA, 1977. Competição de espécies e procedencias de eucalipto na região de Viçosa, Minas Gerais. Revista Arvore, Viçosa, $1(2): 72-88$.

HAAG, H.P., J.R. SARRUGE, G.D. de OLIVEIRA, F. POGgIANi e C. A. FERREIRA, 1976. Análise foliar em cinco espécies de Eu caliptos. IPEF, Piracicaba, (13): 99-115.

HAAG, H.P., J.W. SIMÕES, G.D. de OLIVEIRA, J.R. SARRUGE e F. POGGIANI, 1977. Distürbios nutricionais em Eucalyptus citriodora. IPEF, Piracicaba (14): 59-68.

HAGNER, S., 1971. The present standard of pratical forest fertilization in diferent parts of the world. 'In: IUFRo CONGRESS, 15, Gainsville. Proceedings. 16 p.

HALL, N., R.D. JOHNSTON e G.M. CHIPENDALE, 1970. Forest trees of Australia. 3a ed. Canberra, Australian Government Publishing Service. 330 p.

HANSEN, EaA。 e J.B. BAKER, 1979. Biomass and nutrient removal in short rotation intensively cultured. Annual meeting North American Poplars Council, Thompsonville, p. 130-51. 
HOYLE, M.C. e D.L. MADER, 1964. Relationships of foliar nutrients to growth of red pine in Western Massachesetts. Forest Science, Washington, 10(3): 337-47.

ISIK, K., 1978. White fir growth and foliar nutrient concentration in California plantations. Forest Science, Washington; $24(3): 374-84$

JACOB, A. e H. WEXKULL, 1961. Nutricion y abonado de los ciul tivos tropicales y subtropicales. Wageningen, Veenman I Zonen. $625 \mathrm{p}$.

KRAMER, P.J. e T.T. KOZLOWSKI, 1979. Physiology of Wood Plants. New York, Academic Press. 811 p.

LADIGES, P. e D.H. AHSTON, 1977. A coinparison of some population of Eucalyptus viminalis Labil1, growing on calcareous and acid sets in Victoria, Australia. AustraZian Journal of Ecology, Canberra 2: 161-78.

LAVENDER, D.P. e R.L. CARMICHAEL, 1966. Effect.of three variables on mineral concentrations in Douglas-fir needles. Forest Science, Washington, $12(4): 441-6$.

LUBRANO, L., 1972. Richerce sulle esigenze nutritive di alcune species di Eucalitti.. Pubblicazioni del Centro di Sperimentazione Agricola e Forestale, Rome, 11: 1-15. 
Mc COLL, J.G. e F.R. HUMPHREYS, 1967. Relationships between some nutritional factors and the distributions of Eucalyp: tus gummifera and Eucalyptus maculata. Ecology, Durham 48 (5): 766-71.

MELLO, H.A., J.W.SIMÕES, J.MASCARENHAS SOBREINHO e H.T.Z. do couto, 1971. Influéncia do espaçamento na produção de madeira de eucalipto em solos de cerrado. IPEF, Piracicaba, $(2 / 3): 3-30$.

MERGEN, F。 e J. WORRALL, 1964. Effect of environment and seed source on mineral content of Jack Pine seedlings. Forest Science, Washington, 11(4): 393-400.

POGGIANI, F., H.T.Z. do COUTO e J.W.SIMÓES, 1979. Aspectos ecolögicos das mini-rotações e do aproveitamento dos residuos florestais. Circular técnica, IPEF, Piracicaba, (74): $1-7$.

POGGIANI, F., H.T.Z。 do GOUTO e W. SUITER FILHO, 1983. Biomass and nutrient estimates in short rotation intensively cultured plantation of Eucalyptus grandis. IPEF, Pi racicaba, (23): 37-42.

PRITCHETT, W.L., 1979. Site preparation and fertilization of slash pine on Wet Savana Soil. Southern Journal of Applied Forestry., Washington, $3(3): 86-90$. 
RAIJ, B., 1981. Avaliasão da fertilidade do solo. Piracicaba, Instituto da Potassa \& Fosfato. 142. p.

RENNIE, P.S., 1955. The uptake of llutrients by mature forest growtio Plant Soil, The Hague; $7:$ 49-95.

SARRUGE, J.R。 e H.P. BAAG, 1974. Anälises químicas em plantas. Piracicaba, ESALQ/USP. $58 \mathrm{p}$.

SILVICULTURE, 1964/65. Tree nutrition and soil fertility. Reprint Forest Research Institute New Zealand forestry Service. No 25/26. Apud: Forestry Abstracts. Oxford; 27 (4): 623 .

SOUZiA, A.P. de, R.M. DELla Lucia e G.C. de RESENDE, 1979. Es tudo da densidade básica da madeira de Eucalyptus microcorys F. Muell, cultivado na região de lionisio, MG. Revista. Arvore, vicosa, $\underline{3}(1): 16-27$.

SWITZER, B.S. e NELSON, L.E., 1972. Nutrient Accumulation and cicling in Loblolly Pine (Pinus taeda Lo) Plantations Ecosystems: The First Twenty years. Soil Science Society Amerioan Proccedings, Madison。 $36(1): 143-7$.

TEMES, SoB。, 1970. Study of Eucalyptus globulus. Mineral consticuint of the leaves in relation to their position on the tree. Soil Constituinte and tree. Age. Comum. Inst. For Invet. Exp. Madrid n: 67, p. 48 . 
VEIGA, A.A., 1975. Balancos hidricos das dependências da divisão de florestas e estacões experimentais. São Paulo, Instituto Florestal, v. 1 .

VENTURA, A., G. BERENGUT e M.A.M: VICTOR, 1965/66. Caracteristicas edafo-climaticas das dependencias do Serviço florestal do Estado de São Pualo. Silvicultura em São Paulo, São Paulo, 4/5(4): 57-140.

WALKER, L.C. e R.D. HATCHER, 1965. Variation in the ability of slash pine progenu groupe to absorb nutrients. Proceedings of Soil Science Society of America: 29: 616-21.

WALTER, H., 1977. Vegetation of the Earth: in relation to climat and the eco-physiological conditions. New York, Springer-Verlag。 237 p.

WEETMAN, G.E. e B. WEBBER, 1972. The influence of wood harvesting of the nutrient status of two spruce stands. Canadian Journal of Forest Research, Ottawa; 2: 351-59.

WHITE, R.0., 1960. Crop production and environment. London, Faber and Faber. 392 p.

WOOD, B.W., R.F. WITTWER e S.B. CARPENTER, 1977. Nutrient element accumulation and distribution in an intensively cultured American sucamore plantation. Plant and Soil, The Hague, $48(2): 417-33$. 
WRITE, D.P., 1954. Variation in the nitrogen, phosphorus and potassium contents of pines needles with season, crown position and samples treatment. Proceedings of Soil Science Society of America. 18(3): 326-30.

YOUNG, H.E. e P.N. CARPENTER, 1976. Samplig variation of nutrient element content within and between trees of the same species. In: OSLO BIOMASS STUDIEE, 0s1o. p. 75-99.

ZEN, S., F. POGGIANI e H.T.Z. do COUTO, 1981. Variação dả concentração de nutrientes ao longo do caule de Eucalyptus saligna: implicações na utilização energētica dos resíduos florestais. Circular Técnica IPEF, Piracicaba, (136):1-7. 
.85

8. APENDICE 


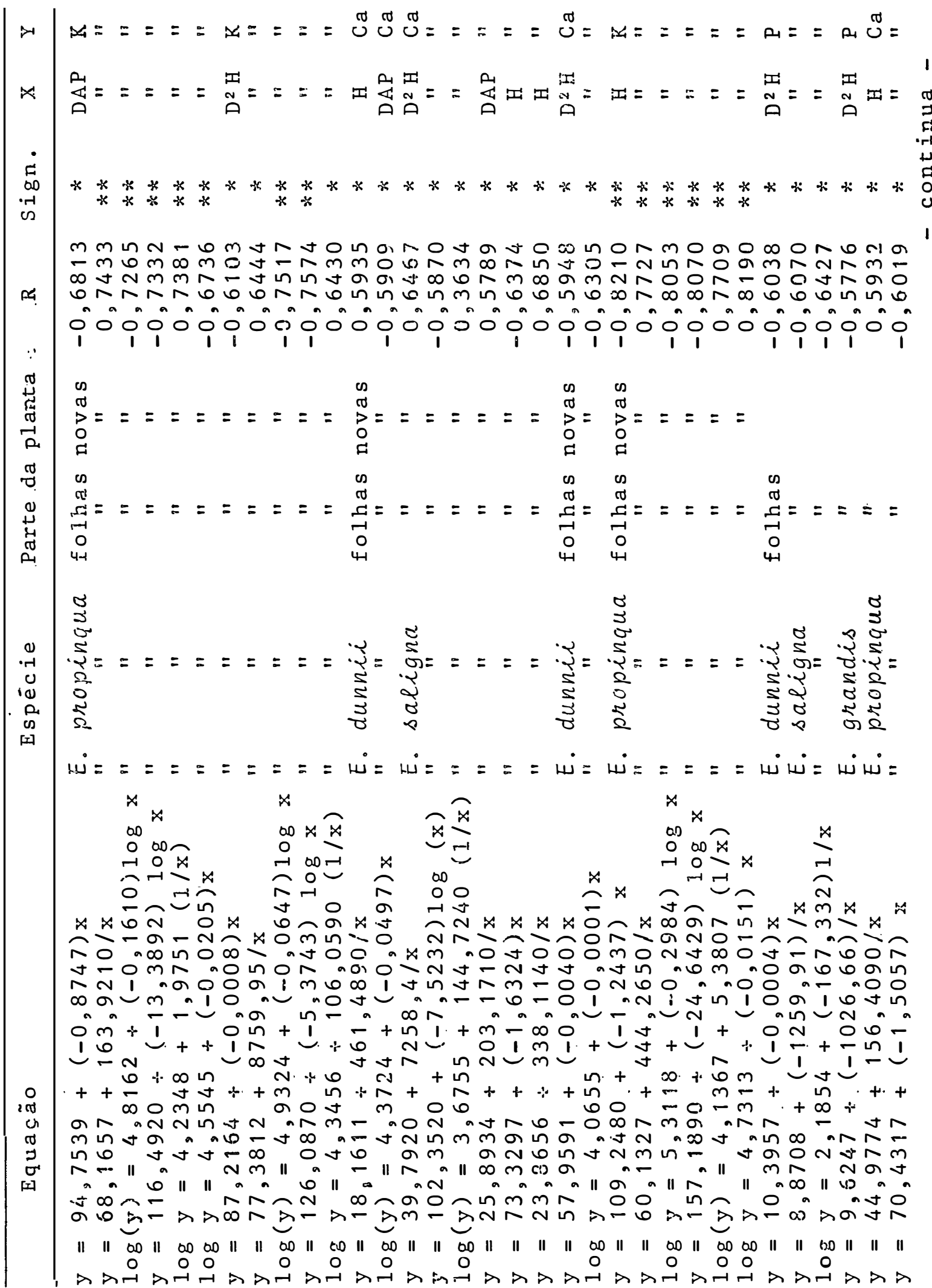




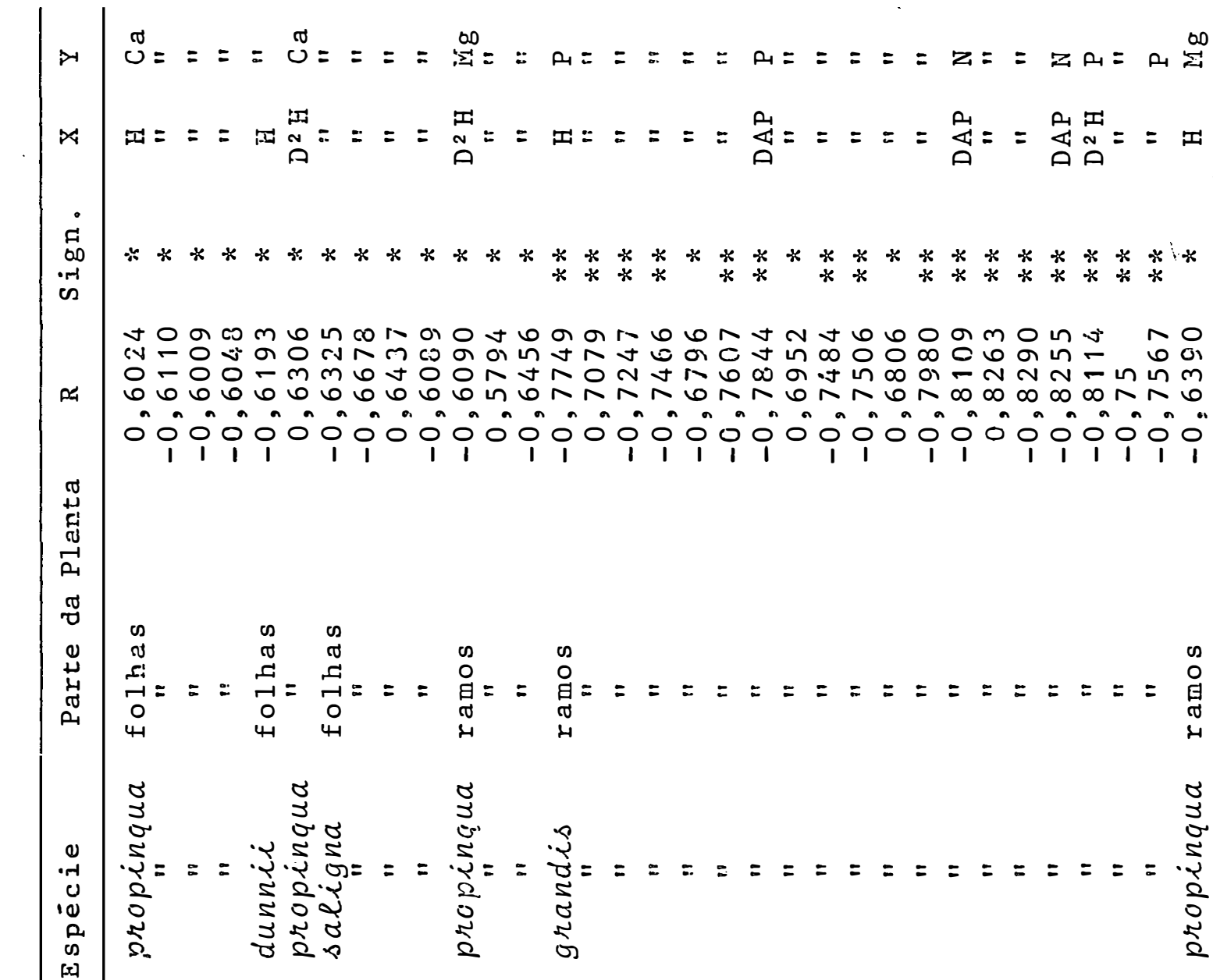

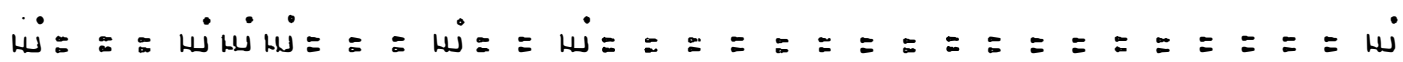

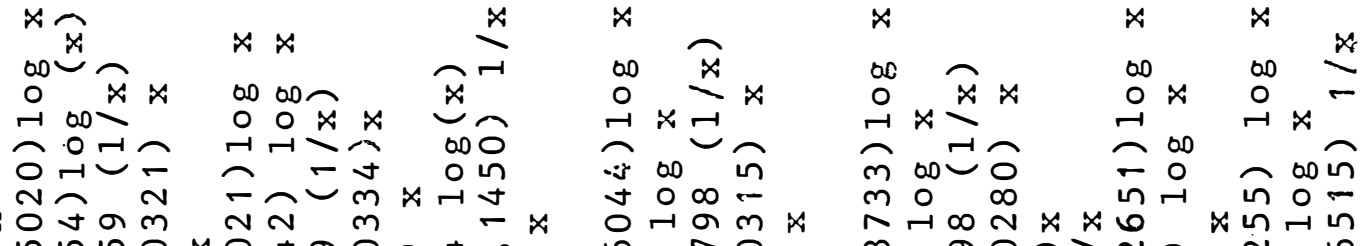
x०才am NN m $-x$ O 으의

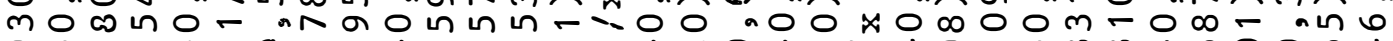

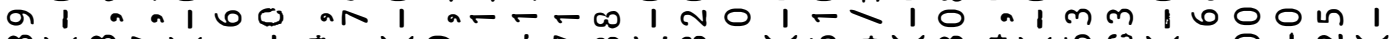

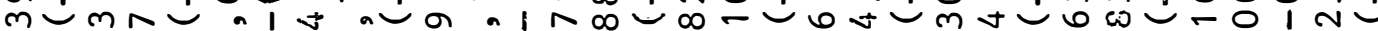

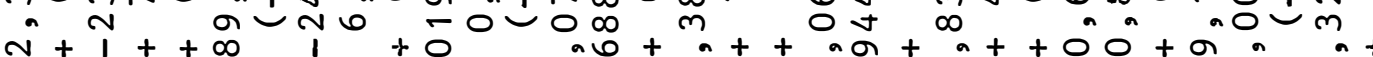

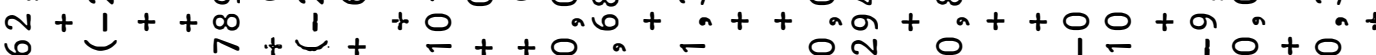

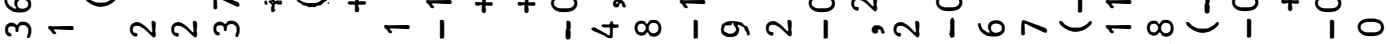

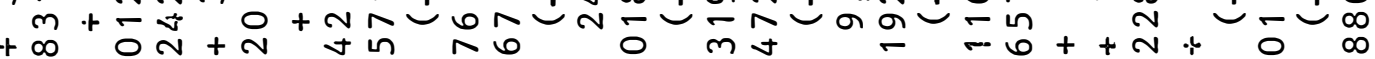
- $0 m m$ a 0 in $m+N \infty++N+m$ nn $+\infty+i n d+N+i n$ $\infty$ ar a a $0-6 m$ a $N 0$ a a a a a an 0 a $\infty$ nnmy-avay a a t n n बै \|

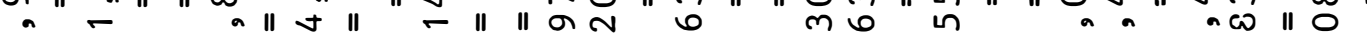

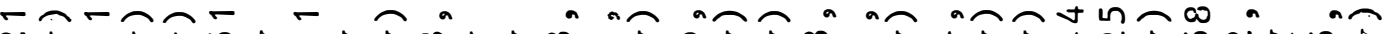

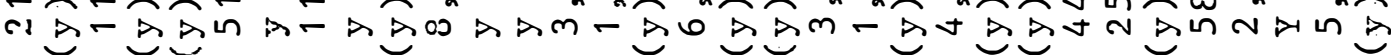
$\|$ |

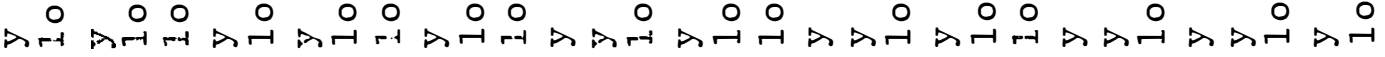




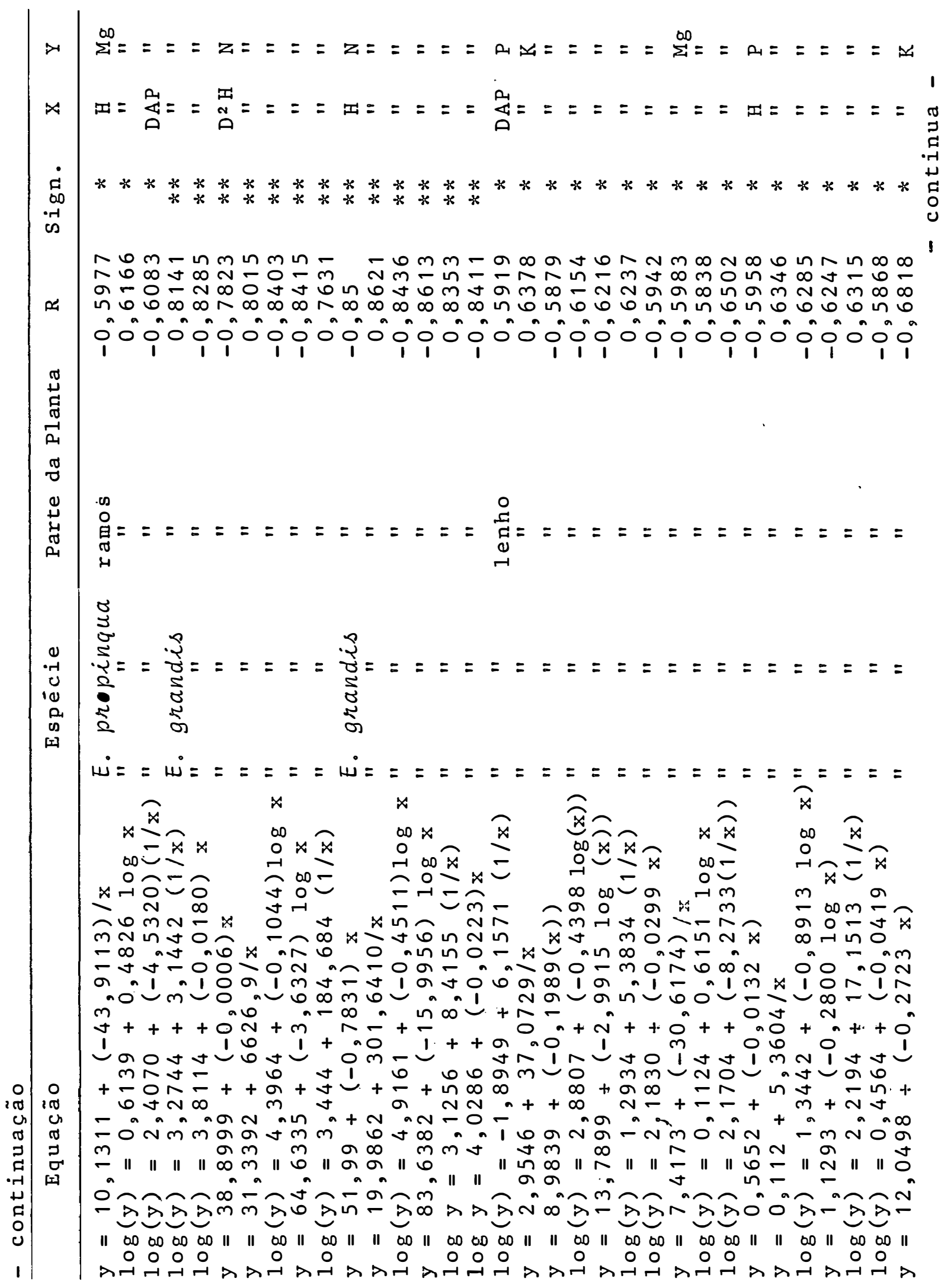




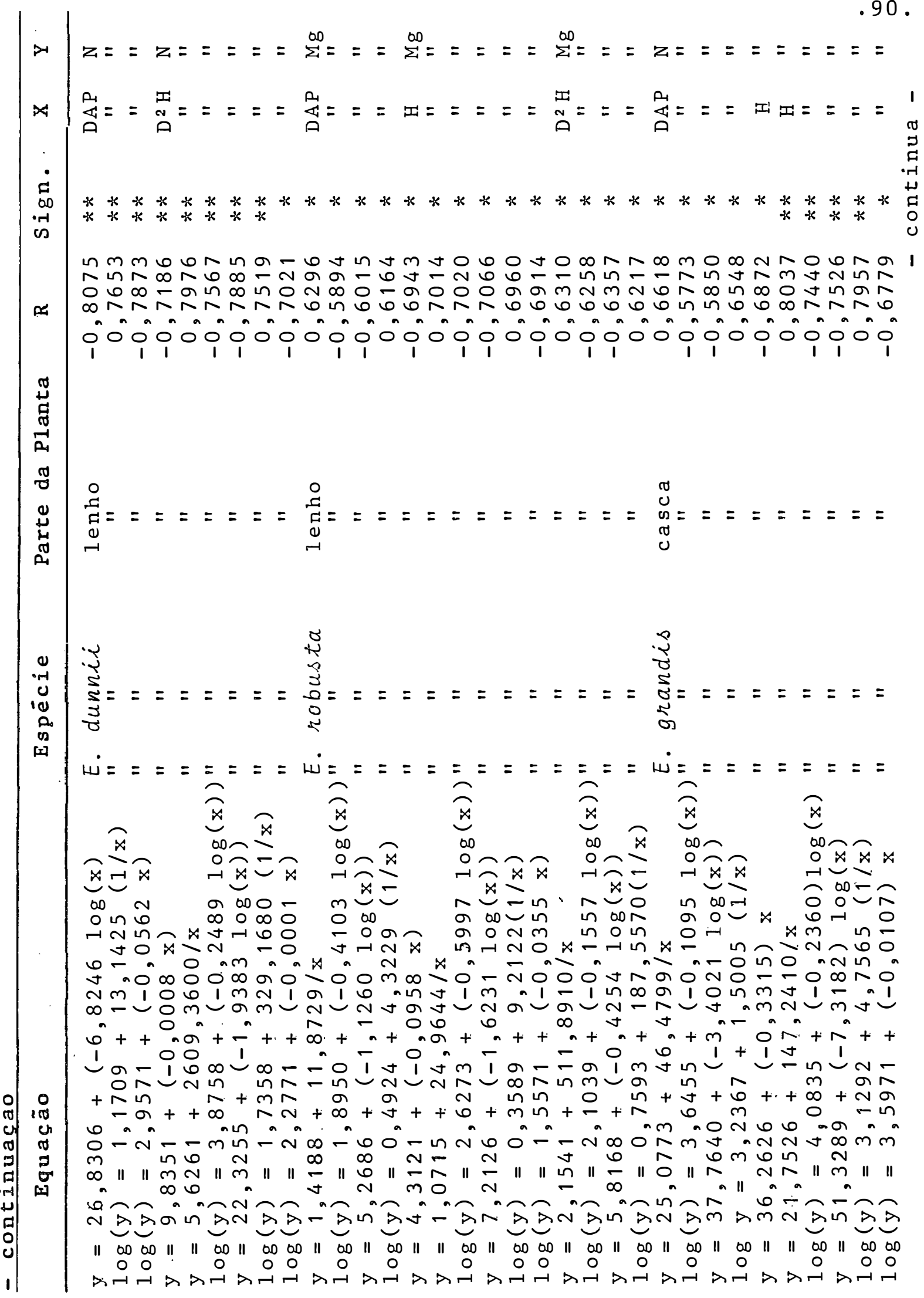




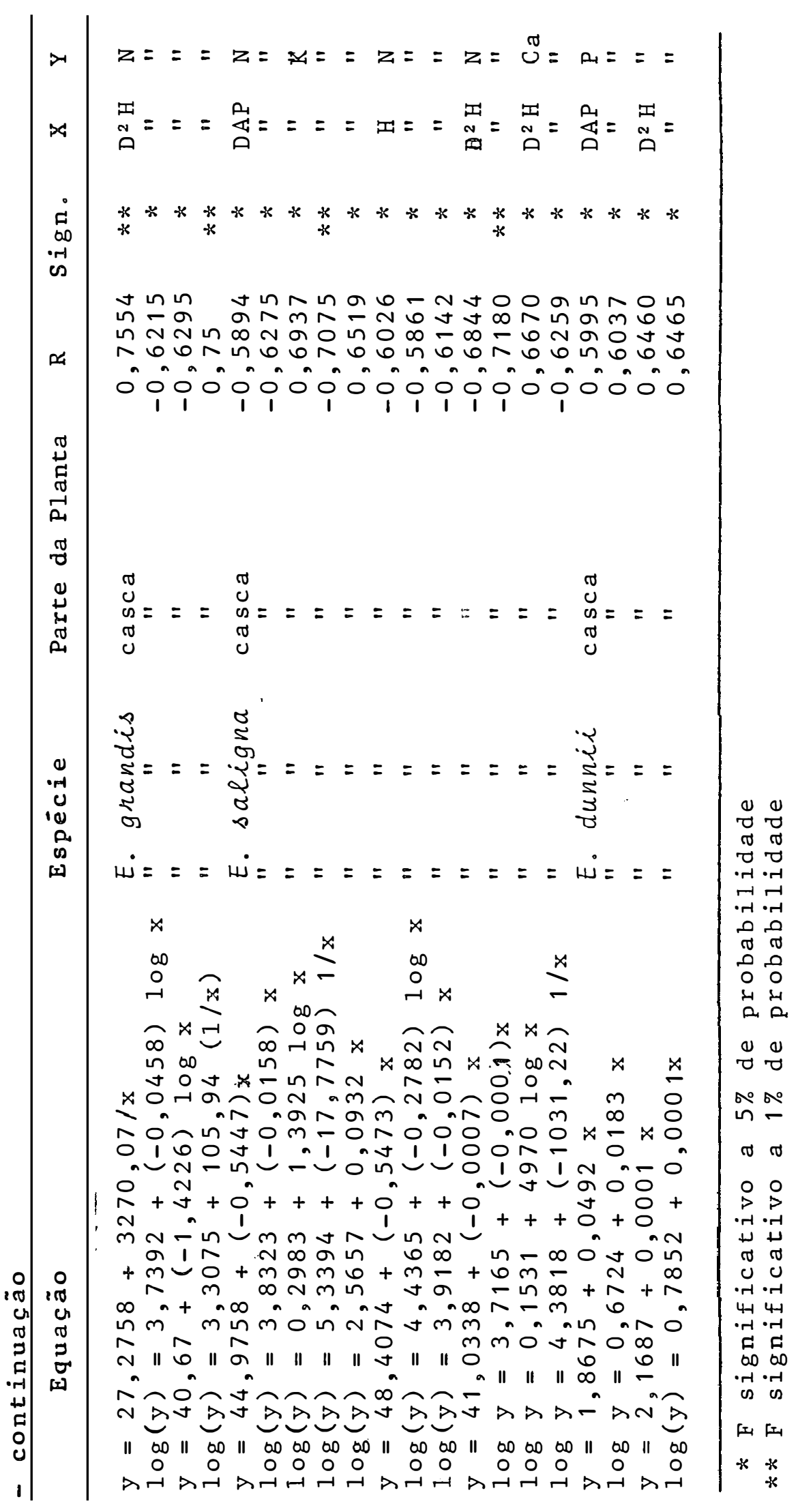

